\title{
Association of Radionuclides with Streambed Sediments in White Oak Creek Watershed
}

\author{
B. P. Spalding \\ T. E. Cerling
}

ENVIRONMENTAL SCIENCES DIVISION

Publication No. 1351 


\section{DISCLAIMER}

This report was prepared as an account of work sponsored by an agency of the United States Government. Neither the United States Government nor any agency Thereof, nor any of their employees, makes any warranty, express or implied, or assumes any legal liability or responsibility for the accuracy, completeness, or usefulness of any information, apparatus, product, or process disclosed, or represents that its use would not infringe privately owned rights. Reference herein to any specific commercial product, process, or service by trade name, trademark, manufacturer, or otherwise does not necessarily constitute or imply its endorsement, recommendation, or favoring by the United States Government or any agency thereof. The views and opinions of authors expressed herein do not necessarily state or reflect those of the United States Government or any agency thereof. 


\section{DISCLAIMER}

Portions of this document may be illegible in electronic image products. Images are produced from the best available original document. 


\section{Printed in the United States of America. Available from}

National Technical Information Service

U.S. Department of Commerce

5285 Port Royal Road, Springfield, Virginia 22161

Price: Printed Copy $\$ 5.25$; Microfiche $\$ 3.00$

This report was prepared as an account of work sponsored by an agency of the United States Government. Neither the United States Government nor any agency thereof, nor any of their employees, contractors, subcontractors, or their employees, makes any warranty, express or implied, nor assumes any legal liability or responsibility for any third party's use or the results of such use of any information, apparatus, product or process disclosed in this report, nor represents that its use by such third party would not-infringe privately owned rights. 
ORNL/TM-6895

Contract No. W-7405-eng-26

\section{ASSOCIATION OF RADIONUCLIDES WITH STREAMBED SEDIMENTS IN WHITE OAK CREEK WATERSHED}

B. P. Spalding and T. E. Cerling

ENVIRONMENTAL SCIENCES DIVISION

Publication No. 1351

Date Published: September 1979

NOTICE This document contains information of a preliminary nature. It is subject to revision or correction and therefore does not represent a final report.

OAK RIDGE NATIONAL LABORATORY

Oak Ridge, Tennessee operated by

UNION CARBIDE CORPORATION for the DEPARTMENT OF ENERGY
- NOTICE

This report was prepared as an account of work sponsored by the United States Govemment. Neither the United States nor the United States Department of Energy, nor any of their employees, nor any of their contractors, subcontractors, or the ir employees, makes any warranty, express or implied, or assumes any lega liability or responsibility for the accuracy, completeness ot usefulness of any information, apparatus, product or process disclosed, or represents that its use would no infringe privately owned rights. 


\section{THIS PAGE}

\section{WAS INTENTIONALLY}

LEFT BLANK 


\section{ABSTRACT}

SPALDING, B. P., and T. E. CERLING. 1979. Association of radionuclides with streambed sediments in White Oak Creek Watershed. ORNL/TM-6895. Oak Ridge National Laboratory, Oak Ridge, Tennessee. 54 pp.

Radionuclides are found in much higher concentrations on streambed sediment than in the water of White Oak Creek. Selective extraction of sediments demonstrates that ${ }^{60} \mathrm{Co}$ is immobilized in a nonexchangeable form in the ferromanganese hydrous oxide coatings on the sediments; ${ }^{90} \mathrm{Sr}$ occurs predominantly in an exchangeable form on clay, iron oxides, and ferromanganese hydrous oxides; ${ }^{137} \mathrm{Cs}$ occurs in a nonexchangeable and strongly bound form on clays which compose the dominant rock (Conasauga shale) in the watershed. The fine-gravel to coarse-sand size fraction of streambed sediments is the most suitable fraction for radionuclide analysis because of its abundance in the sediment and its high concentration of radionuclides compared to larger and smaller size fractions. A preliminary survey of all major tributaries in White Oak Creek shows that radionuclide analys is of streambed sediments is a very useful technique to locate sources of radioactive contamination. 


\section{THIS PAGE}

\section{WAS INTENTIONALLY}

\section{LEFT BLANK}


TABLE OF CONTENTS

$\underline{\text { Page }}$

ABSTRACT ...........................

LIST OF TABLES ................................. vii

LIST OF FIGURES ....................... ix

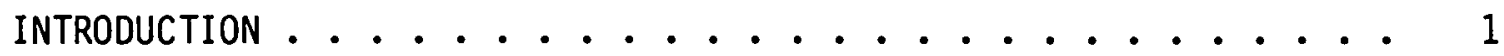

EXTRACTION OF METALS AND RADIONUCLIDES

AND THEIR RELATIONSHIP TO MINERALOGY ........... 4

Experimental ........................ 6

Evaluation of Extractants .............. 6

Sequential Dissolution ............. 6

Radiochemical Analyses .............. 8

Results and Discussion ................... 9

ADSORPTION OF ${ }^{85}$ SR TO STREAMBED MATERIALS ......... 21

Experimental ............................ 22

Lithologic Materials ............... 22

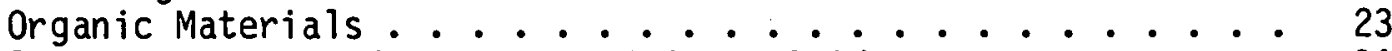

Synthetic Iron and Manganese Hydrous Oxide ....... 24

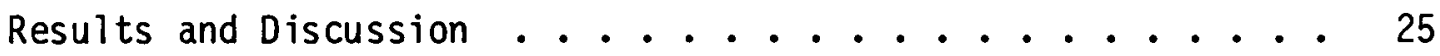

OPTIMUM SIZE FOR SEDIMENT SAMPLING ............ 27

Experimental ......................... 27

Results and Discussion ................... 28

SURVEY OF WHITE OAK CREEK STREAMBED SEDIMENTS . . . . . . . 32

SUMMARY AND CONCLUSIONS ............................ 40

REFERENCES .............................. 42 
THIS PAGE.

WAS INTENTIONALLY

LEFT BLANK 


\section{LIST OF TABLES}

Table

Page

1 Extractions used for $\mathrm{Fe}, \mathrm{Mn}$, and radionuclides and mechanism of each extractant ............

2 Extraction of $\mathrm{Fe}, \mathrm{Mn},{ }^{60} \mathrm{Co}$, from coarse sand (3.35 to $0.85 \mathrm{~mm}$ ) contaminated with $60_{\mathrm{Co}} \ldots . . . . .10$

3 Sequential dissolution of a ferromanganese coating scraped from a shaley limestone cobble from Melton Branch of White Oak Creek. The second set shows that heating the sample to $80 \mathrm{C}$ prior to dissolution has little effect on the extractions .................

4 Extraction of $\mathrm{Fe}, \mathrm{Mn},{ }^{90} \mathrm{Sr}$, and ${ }^{137} \mathrm{Cs}$ from coarse sand $(3.35$ to $0.85 \mathrm{~mm})$ of streambed sediment contaminated with $90{ }_{\mathrm{Sr}}$ and $137 \mathrm{Cs} \ldots \ldots . \ldots$

5 Sequential dissolution of an Fe gel collected at a radioactive groundwater seep in SWDA-4 ........ 17

6 Radionuclide and extractable $\mathrm{Fe}$ and Mn content of streambed gravel $(4.75$ to $2.0 \mathrm{~mm})$ segregated by color....

7 Distribution coefficient $\left(K_{d}\right)$ of ${ }^{85} \mathrm{Sr}$ between white 0ak Creek water and streambed gravels, sediments, organic matter, and Fe-Mn oxides ................

8 Radionuclide and extractable $\mathrm{Fe}$ and $\mathrm{Mn}$ of streambed sed iment size fractions . . . . . . . . . . . . .

9 Radionuclide concentrations of streambed sediment samples of White Oak Creek watershed 


\section{THIS PAGE}

WAS INTENTIONALLY

LEFT BLANK 


\section{LIST OF FIGURES}

Figure

Page

1 Location of solid waste disposal areas (SWDA's) and intermediate-level waste (ILW) pits and trenches in white Oak Creek watershed . . . . . . . . . . . . . . 2

2 The relationship between ${ }^{60} \mathrm{Co}$ and Mn extractabilities by various solutions from a sample of contaminated streambed sediment . . . . . . . . . . . . . . .

3 Percent loss of each component from the manganese oxide-coated shale during sequential dissolution . . . .

4 Percent loss of each component from the Fe sol during

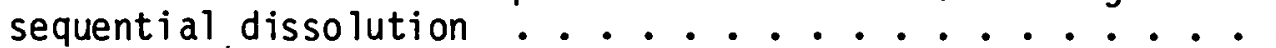

5 The distribution of quartz, ${ }^{137} \mathrm{Cs}$, and ${ }^{90} \mathrm{Sr}, \mathrm{Mn}$, and Fe extractable by hydroxylamine in size fractions of contaminated streambed sediment ............

6 Location of streambed sediment samples from White 0ak Creek watershed. Sample identification numbers correspond to the radiochemical concentrations listed in Table 6 . . . . .

7 The distribution of $90 \mathrm{Sr}$ concentrations in streambed sediment samples from White Oak Creek watershed . . . . . . 36

8 The distribution of ${ }^{137} \mathrm{Cs}$ concentrations in streambed sediment samples from White Oak Creek watershed . . . . . . 37

9 The distribution of ${ }^{60} \mathrm{Co}$ concentrations in streambed sediment samples from White Oak Creek watershed . . . . . 38 


\section{INTRODUCTION}

\section{Although several general sources of radiochemical contamination}

entering White Oak Creek (Fig. 1) are known, the estimated releases from these sources fall considerably below the total monitored releases leaving the watershed at White Oak Dam (Stueber et al. 1978). Thus, unknown sources as well as imprecisely located known sources of contamination exist in the watershed. These must be identified before abatement measures can be effectively applied. Analysis of the radiochemical concentrations in stream water and groundwater offers an effective method of locating these sources, but this method has some limitations. Water analysis has a comparatively limited sensitivity, at least when employing sample volumes less than a liter, due to the large dilution of radionuclides by uncontaminated water flowing through the watershed. Sediment analys is offers a considerable increase in sensitivity for radionuclide detection, particularly at point sources of contamination; the laboratory values for distribution coefficients $\left(K_{d}=d p m / g\right.$ in solid $\div \mathrm{dpm} / \mathrm{ml}$ in water) for radionuclides in local groundwater with Conasauga shale, which composes most of the sediment in Melton valley, are high: $120,70,000$ and $\geq 100,000 \mathrm{ml} / \mathrm{g}$ for ${ }^{90} \mathrm{Sr}$, ${ }^{60} \mathrm{Co}$, and ${ }^{137} \mathrm{Cs}$, respectively. Sediment analysis also provides a short-term history of the surrounding stream water composition, particularly for the more strongly adsorbed radionuclides. In addition, the larger-sized components of stream sediment are transported more slowly by flowing water and, thus, may represent stationary monitors of the radionuclide concentrations in stream waters. 


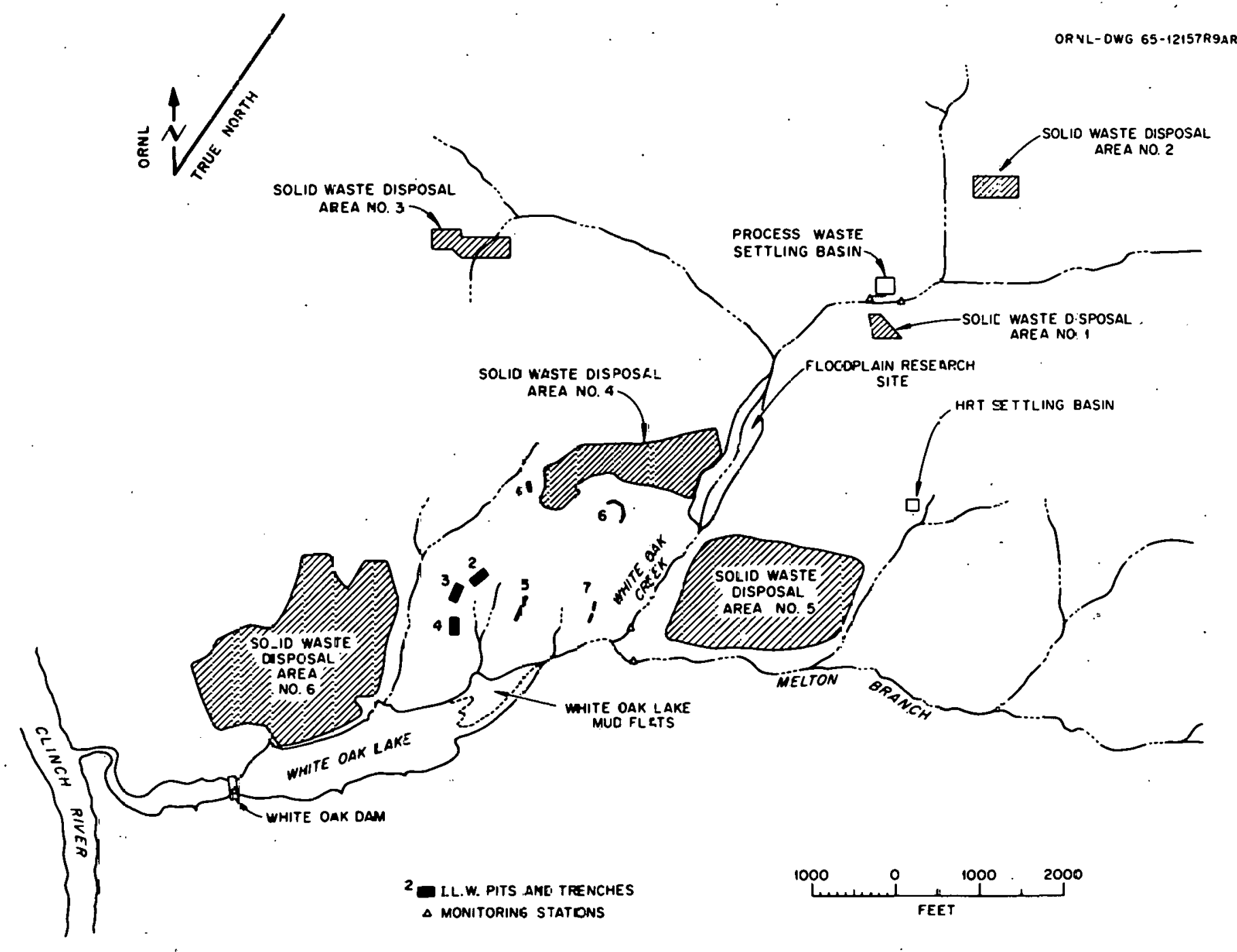

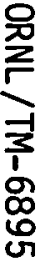

Fig. 1. Location of solid waste disposal areas (SWDA's) and intermediate-level waste (ILW) pits and trenches in white Oak Creek watershed. 
This study was undertaken to evaluate the potential use of streambed sediments for locating and monitoring radionuclide contamination in white 0ak Creek. Only ${ }^{90} \mathrm{Sr},{ }^{137} \mathrm{Cs}$, and ${ }^{60} \mathrm{Co}$ were examined because these comprise most of the radioactivity, with the exception of tritium, released into white Oak Creek. Each of the radionuclides was examined for its interaction with streambed sediment using several approaches. Contaminated sediment was extracted with water, salt/buffer solutions, and reducing agents to observe the distribution of each radionuclide in various phases: soluble, exchangeable by other cations, or precipitated with ferromanganese hydrous oxides, respectively. The ferromanganese hydrous oxide phase, which coats many of the sediments in White Oak Creek, was examined because of its known importance in the adsorption and immobilization of transition elements (Jenne 1968) including ${ }^{60} \mathrm{Co}$, and because several common manganese minerals contain alkaline earth elements (McKenzie 1977) including ${ }^{90} \mathrm{Sr}$. In addition, the distribution of each radionuclide in different size classes of sediment was examined to determine which sizes are most contaminated and, therefore, most suitable for routine monitoring.

Since the initial investigations described above generated some interesting observations, additional and more basic investigations of radionuclide-sediment interactions were initiated. Several hydrous iron oxide precipitates (sols) and isolated ferromanganese hydrous oxide coatings were examined by selective chemical dissolution to elucidate the form and mechanism of radionuclide adsorption and precipitation. Several mechanisms could account for the association of 
each radionuclide with these hydrous oxides including coprecipitation, cation exchange by either the oxides themseives, or organic matter inclusions produced by microbial growth or entrapment of particulates from stream water. Particular attention also was focused on the potential interaction of $\mathrm{Sr}$ with different types of sediment. Organic detritus in varying stages of decomposition and mineralogically different rocks were examined for their ability to adsorb $\mathrm{Sr}$ from strcam watcr spiked with ${ }^{85} \mathrm{Sr}$.

Finally, a preliminary survey was made of the radionuclide content of the fine gravel and coarse sand fractions of streambed sediments from throughout White 0ak Creek watershed. Samples were taken from all major streams above and below known or suspected areas of contamination. This information is needed to select areas or sections of streams which will require more intensive sampling to locate sources of contamination entering the watershed.

\section{EXTRACTION OF METALS AND RADIONUCLIDES AND}

THEIR RELATIONSHIP TO MINERALOGY

Several different extractants were evaluated for their ability to extract iron, manganese, ${ }^{60} \mathrm{Co},{ }^{90} \mathrm{Sr}$, and ${ }^{137} \mathrm{Cs}$ from stream sediments. These included cation exchangers, acids, oxidizing agents, chelating agents, and reducing solutions (Table 1 ). Two different samples were examined: one contaminated with both ${ }^{90} \mathrm{Sr}$ and ${ }^{137} \mathrm{Cs}$ and the other contaminated with ${ }^{60}$ Co. 
Table 1. Extractants used for $\mathrm{Fe}, \mathrm{Mn}$, and radionuclides and mechanism of each extractant

\begin{tabular}{|c|c|c|c|c|c|c|}
\hline \multirow[b]{2}{*}{ Extractant } & \multicolumn{5}{|c|}{ Mechanism ${ }^{\mathrm{a}}$} & \multirow[b]{2}{*}{ Comments } \\
\hline & (1) & (2) & (3) & (4) & $(5)$ & \\
\hline Tapwater & & & & & & \\
\hline $1 \underset{\mathrm{N} \text { ammonium }}{\text { acetate } \mathrm{pH}=7}$ & $x$ & & & $x$ & & \\
\hline $1 \underline{\mathrm{N} \mathrm{NaCl}}$ & $x$ & & & & & \\
\hline $\begin{array}{c}0.3 \mathrm{M}_{\text {citrate }} \mathrm{NH}_{4}- \\
\text { cits }\end{array}$ & $x$ & & & $x$ & . & . \\
\hline $\begin{array}{l}3 \% \mathrm{H}_{2} \mathrm{O}_{2} \text { in } \\
0.01 \\
\mathrm{M}\end{array} \mathrm{HNO}_{3} \mathrm{~b}$ & . & $x$ & $x$ & & $x$ & $\begin{array}{l}\text { Reduces Mn (IV) but } \\
\text { oxidizes organic matter }\end{array}$ \\
\hline 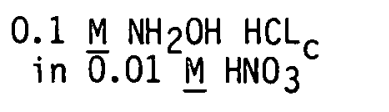 & $x$ & $x$ & & & $x$ & \\
\hline $\begin{array}{l}2 \% \mathrm{NH}_{2} \mathrm{OH} \mathrm{HCL} \text { in } \\
0.3 \mathrm{M} \mathrm{NH}_{4}^{-} \\
\text {citrate, pH } 7 \mathrm{~d}\end{array}$ & $x$ & & & $x$ & $x$ & \\
\hline${ }_{\mathrm{pH}}^{0.2} \frac{\mathrm{M}}{2} \mathrm{e}^{\mathrm{NH}_{4}-0 \times a l a t e}$ & $x$ & $x$ & & $x$ & · & $\begin{array}{l}\text { Precipitates } \mathrm{Ca}, \mathrm{Mg}, \mathrm{Sr} \\
\text { oxalate }\end{array}$ \\
\hline $\begin{array}{rl}0.2 & \mathrm{~g} / \mathrm{g} \mathrm{Na} 2 \mathrm{~S}_{2} \mathrm{O} 4 \\
\text { in } 0.3 \mathrm{Na} \text { citrate, } \\
\mathrm{pH} 4.8 \mathrm{f}\end{array}$ & $x$ & $x$ & & $x$ & $x$ & \\
\hline $8 \underline{\mathrm{N}} \mathrm{HNO}_{3}$ & $x$ & $x$ & & & & $\begin{array}{l}\text { At high temperature, } \\
\text { structural alteration } \\
\text { of clay }\end{array}$ \\
\hline
\end{tabular}

a(1). Exchangeable (exchange sites on clay, organic matter, Fe-Mn oxides); (2) acid (metals, organic matter, carbonates, some silicates); (3) oxidizing agent (organic matter); (4) chelating agent (Fe and $\mathrm{Mn}$, some organic matter); (5) reducing agent ( $\mathrm{Fe}$ and $\mathrm{Mn}$ ).

bTaylur et al. 1964.

CChao 1972.

dWitney 1975.

- eMcKeague and Day 1966.

f Coffin 1963. 
In conjunction with this study, sequential dissolutions of a, contaminated iron sol and a contaminated manganese coating were carried out to help determine the association of radionuclides with different minerals present in stream gravels.

\section{Experimental}

\section{Evaluation of Extractants}

Ten-gram duplicates of the ${ }^{90} \mathrm{Sr}$ - and ${ }^{137} \mathrm{Cs-contaminated}$ sediments were placed in 25- $\times 150-\mathrm{m}$ test tubes and extracted twice with $30 \mathrm{ml}$ and once with $20 \mathrm{ml}$ of one of solutions (Table 1) by swirling, waiting one hour, swirling again, and decanting the solution. Combined decantings were filtered by washing through Whatman No. 40 paper to remove the small amount of particulate matter produced during extraction, and were made to $100 \mathrm{ml}$ with water. The extractions of the ${ }^{60}$ Co-contaminated samples were performed on $1.50 \mathrm{~g}$ samples with two 15-ml and one 10-ml volumes, filtered as above, and made to $50 \mathrm{ml}$. All extractions. were run in duplicate at both ambient (ca. $25^{\circ} \mathrm{C}$ ) and $95^{\circ} \mathrm{C}$ temperatures (in a hot water bath). Each extract was analyzed for manganese by oxidation to permanganate (Adams 1965) and for iron by an o-phenanthroline procedure (Jackson 1956).

Sequential Dissolution

A relatively pure $\mathrm{Fe}$ sol was obtained from a seep in Solid Waste Disposal Area (SWDA) 4 near well 186A; a ferromanganese hydrous oxide separate was obtained by scraping with a stainiess steel spatula the easily flaked-off dark coating on an encrusted shaley limestone cobble 
from Melton Branch. Care was taken to avoid cobbles with excessive algal coatings. The iron sample was separated from the liquid phase by centrifugation at $600 \mathrm{RCF}$ for $30 \mathrm{~min}$; the aqueous phase was analyzed after three weeks. The ferromanganese sample was split; one-half was air-dried and the remainder was dried at $80^{\circ} \mathrm{C}$. Samples were treated with progressively more destructive reagents and each leachate was then analyzed for $\mathrm{Fe}, \mathrm{Mn},{ }^{60} \mathrm{Co},{ }^{90} \mathrm{Sr}$, and ${ }^{137} \mathrm{Cs}$ as described later. Weight losses were determined after each step; $x$-ray diffraction patterns were run after the removal of iron and clay minerals. Reagents used were: ammonium acetate buffered to $\mathrm{pH} 7$ to remove exchangeable cations (Jackson 1956); repeated $\mathrm{H}_{2} \mathrm{O}_{2}$ treatments followed by extraction with $1 \underline{\mathrm{N}}$ sodium-acetate at $\mathrm{pH} 7$ to remove organics and $\mathrm{MnO}_{2}$ (used on Fe sol on $1 y$ ); $0.3 \underline{M}$ ammonium citrate with $2 \%$ w/V hydroxylamine hydrochloride adjusted to $\mathrm{pH} 7.0$ with ammonium hydroxide to remove $\mathrm{MnO}_{2}$ and poorly crystalline iron oxides (Whitney 1975); and Na-dithionite in $0.3 \underline{M}$ sodium citrate and $0.1 \underline{M}$ sodium bicarbonate to remove iron oxides (Jackson 1956). These treatments resulted in a residue of disaggregated silicate minerals. This residue (in the case of the iron sample, after separating into sand, silt, and clay fractions) was then treated with hot $\mathrm{HNO}_{3}$ for $1 \mathrm{hr}$ at $95^{\circ} \mathrm{C}$. The final dissolution procedure dissolved clay minerals by fusion with sodium pyrosulphate and leaching with $\mathrm{HCl}$ and $\mathrm{NaOH}$ (Kiely and Jackson 1964, 1965). The residue was shown to be quartz containing a trace of feldspar, determined by optical examination under a microscope and by $X$-ray diffraction. Each procedure (except clay dissolution) was 
performed twice, followed by three washings with distilled water which were added to the initial supernatant before analysis.

\section{Radiochemical Analyses}

A $25-\mathrm{ml}$ aliquot was used for the determination of total radiostrontium (American Public Health Service 1975); the barium carrier addition and its precipitation with sodium chromate were not employed because ${ }^{140_{B a}}$ was not present at detectable levels in these samples. In addition, only one scavaging with the mixed rare-earth carrier was employed because samples were counted after full ingrowth of the ${ }^{90} Y$ daughter (21 days). The final precipitate $\left(\mathrm{SrCO}_{3}\right)$ from the radiochemical fractionation was slurried onto a tared 1-in.-diam. aluminum $\mathrm{planchet,} \mathrm{dried,} \mathrm{weighed} \mathrm{to} \mathrm{calculate} \mathrm{carrier} \mathrm{recovery}$ (usually between 70 and $80 \%$ ), and counted on a Beckman Wide Beta II gas-flow proportional counter after ${ }^{90} \gamma$ ingrowth. Counting efficiency was determined using a dilution of standard reference material 4234 (National Bureau of Standards) at various $\mathrm{SrCO}_{3}$ sample thicknesses; typical counting efficiencies were about $42 \%$ depending on carrier recovery. The total observed counts, which represent equal contributions from ${ }^{90} \mathrm{Sr}$ and ${ }^{90} \mathrm{Y}$, were halved to report on $1{ }^{90} \mathrm{Sr}$; this was expressed in dpm/g of oven-dried material.

The extractability of ${ }^{60} \mathrm{Co}$ and ${ }^{137} \mathrm{Cs}$ by each solution was determined by computing the difference in radionuclide content of the sediment before and after extraction. Cesium-137 and ${ }^{60}$ Co were counted with a Packard Model 16 multichannel analyzer equipped with a well-type NaI (Tl-activated) detector. Counting efficiencies were 
determined using single radioisotopic standards (which had previously been compared with NBS standard reference material) prepared in 10-g so il matrices and contained in 25- x 150-m test tubes. Background counts in the ${ }^{137}$ Cs channels window were determined by computing the average counts per channel for the five channels on each side of the window and multiplying this figure by the number of channels in the ${ }^{137} \mathrm{Cs}$ window. The background counts in the ${ }^{60}$ Co channels window were determined by counting empty test tubes because no $\gamma$-emitter with decay energies greater than ${ }^{60}$ Co was present in these samples.

\section{Results and Discussion}

Each radionuclide present in sediment was strongly associated with different mineral phases. The extractability of ${ }^{60} \mathrm{Co}_{0}$ in streambed gravel by.different reagents strongly suggests its association with the ferromanganese hydrous oxide component in the stream sediment (Table 2). Little ${ }^{60}$ Co was water-soluble or exchangeable since tapwater, ammonium acetate, and sodium chloride solutions removed only minor amounts. other extractants removed varying amiouits of ${ }^{60} \mathrm{Co}, \mathrm{Mn}$, and $\mathrm{Fe}$ from the sediment, but the amount of ${ }^{60}$ Co extracted was well correlated $(r=0.93)$ with the amount of Mn extracted (Fig. 2); ${ }^{60}$ Co was less well correlated $(r=0.61)$ with the $\mathrm{Fe}$ extracted, because $\mathrm{Fe}$ and $\mathrm{Mn}$ behaved somewhat independently in their extractabilities $(r=0.65)$. Sequential dissolution of the scraped-off ferromanganese coating showed that all ${ }^{60}$ Co was extracted during the dissolution step which removed 90 to $95 \%$ of the Mn but only about $20 \%$ of the total Fe in the sample (Table 3 and Fig. 3). 

Table 2. Extraction of $\mathrm{Fe}, \mathrm{Mn},{ }^{60} \mathrm{Co}$, from coarse sand (3.35 to $\left.0.85 \mathrm{~mm}\right)$
contaminated with ${ }^{60} \mathrm{Co}$

\begin{tabular}{|c|c|c|c|c|c|c|}
\hline \multirow[b]{2}{*}{ Extractant } & \multicolumn{3}{|c|}{$25^{\circ} \mathrm{C}$} & \multicolumn{3}{|c|}{$95^{\circ} \mathrm{C}$} \\
\hline & $\begin{array}{c}\mathrm{Fe} \\
(\mu \mathrm{g} / \mathrm{g})\end{array}$ & $\begin{array}{c}M n \\
(\mu g / g)\end{array}$ & $\begin{array}{l}{ }^{60} \mathrm{Co} \\
\text { (\% total) }\end{array}$ & $\begin{array}{c}F e \\
(\mu g / g)\end{array}$ & $\begin{array}{c}M n \\
(\mu g / g)\end{array}$ & $\begin{array}{l}{ }^{60} \mathrm{Co} \\
(\% \text { total })^{a}\end{array}$ \\
\hline Tapwater & 3 & $\leq 10$ & 5 & 2 & 10 & 4 \\
\hline $1 \underset{\mathrm{N} \text { ammonium }}{\text { acetate } \mathrm{pH}}=7$ & 1 & 20 & 3 & 2 & 45 & 1 \\
\hline 1 N Nar. & 2 & 18 & 3 & 6 & 29 & 3 \\
\hline $\begin{array}{l}0.3 \mathrm{M}_{\text {citrate }} \mathrm{NH}_{4-} \\
\text { cits }\end{array}$ & 160 & 90 & 13 & 1260 & 460 & 80 \\
\hline $\begin{array}{l}3 \% \mathrm{H}_{2} \mathrm{O}_{2} \text { in } \\
0.01 \text { M } \mathrm{HNO}_{3}\end{array}$ & 28 & 410 & 40 & 18 & 400. & 33 \\
\hline $\begin{array}{l}0.1 \mathrm{M} \mathrm{NH}_{2} \mathrm{OH} \cdot \mathrm{HCl} \\
\text { in } \frac{\mathrm{MCl}}{0.01} \mathrm{M} \mathrm{HNO}{ }_{3}\end{array}$ & 82 & 530 & 44 & 2830 & 840 & 75 \\
\hline $\begin{array}{l}2 \% \mathrm{NH}_{2} \mathrm{OH} \cdot \mathrm{HCl} \text { in } \\
0.3 \mathrm{M} \mathrm{NH}_{4}- \\
\text { citrate, } \mathrm{pH} 7\end{array}$ & 350 & 430 & 64 & 5630 & 630 & 84 \\
\hline $\begin{array}{l}0.2 \mathrm{M} \mathrm{N} \mathrm{Nl}_{4}- \\
\text { nxalate } \mathrm{pH} 2\end{array}$ & 572 & 410 & 54 & 11750 & 660 & 77 \\
\hline 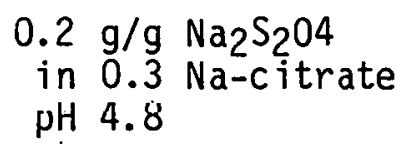 & 14200 & 660 & 77 & 18760 & 480 & 80 \\
\hline $8 \underline{\mathrm{N}} \mathrm{HNO}_{3}$ & 3200 & 490 & 65 & 45270 & 1020 & 98 \\
\hline
\end{tabular}

aTotal 60 Co was $12,500 \mathrm{dpm} / \mathrm{g}$. 


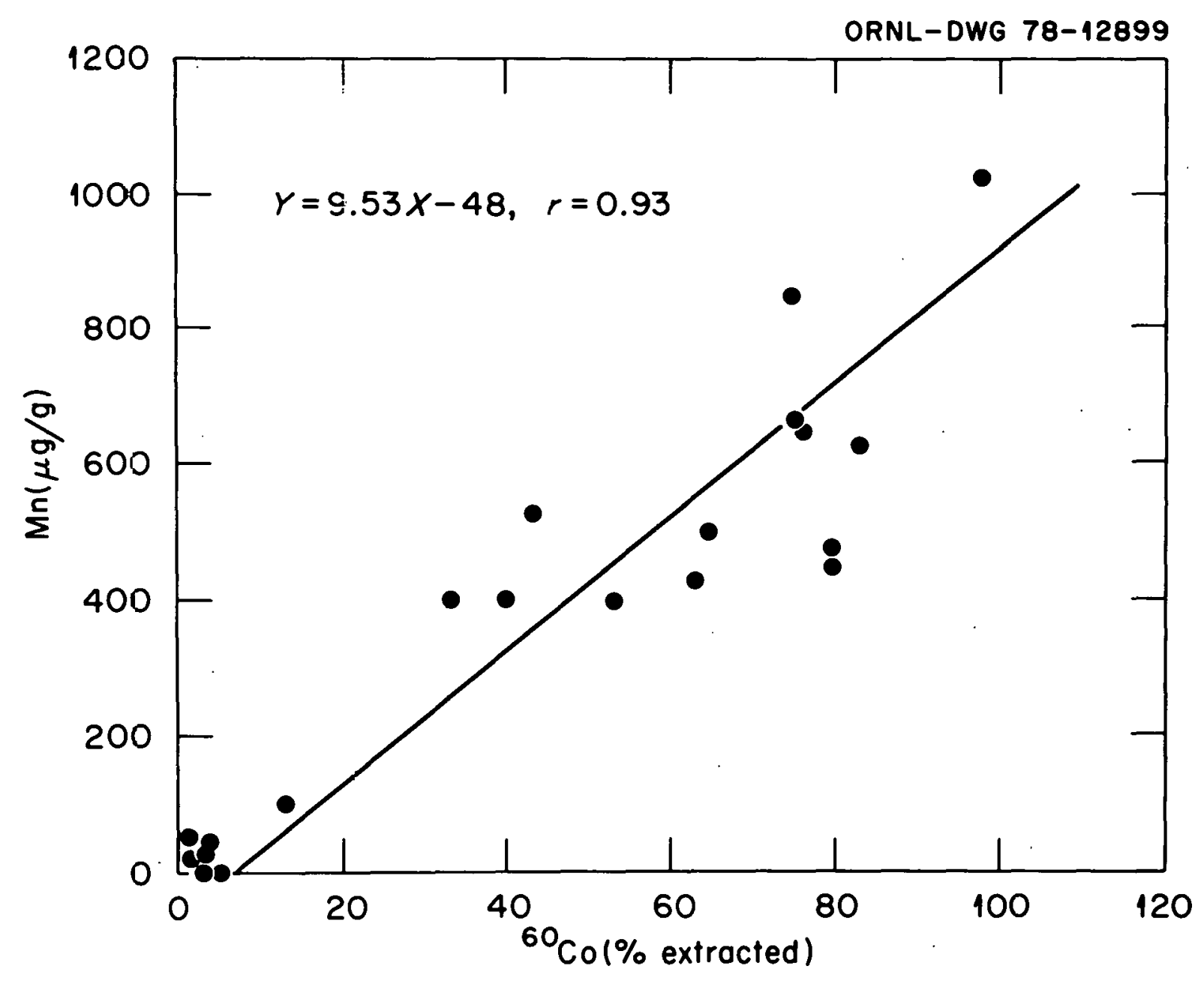

Fig. 2. The relationship between ${ }^{60} \mathrm{Co}_{0}$ and Mn extractabilities by various solutions from a sample of contaminated streambed sediment. 
Table 3. Sequential dissolution of a ferromanganese coating scraped from a shaley limestone cobble from Melton Branch of White Oak Creek. The second set shows that heating the sample to $80^{\circ} \mathrm{C}$ prior to dissolution has little effect on the extractions

\begin{tabular}{|c|c|c|c|c|c|c|}
\hline Treatment & $\begin{array}{l}\text { Weighta } \\
\text { loss } \\
(\mathrm{mg})\end{array}$ & $\begin{array}{l}\mathrm{Fe}_{2} \mathrm{O}_{3} \\
(\mathrm{mg})\end{array}$ & $\underset{(\mathrm{mg})}{\mathrm{MnO}_{2}}$ & $\begin{array}{l}{ }^{137} \mathrm{Cs} \\
(\mathrm{dpm})\end{array}$ & $\begin{array}{r}{ }^{90} \mathrm{Sr} \\
(\mathrm{dpm})\end{array}$ & $\begin{array}{l}{ }^{60} \mathrm{Co} \\
(\mathrm{dpm})\end{array}$ \\
\hline Original & 577.7 & & . & & & \\
\hline $\begin{array}{l}\mathrm{NH}_{4} \text {-acetate, } \\
\mathrm{pH} 7\end{array}$ & & $-b$ & - & - & 113 & - \\
\hline $\begin{array}{l}\mathrm{NH}_{4} \text {-citrate, } 2 \% \\
\mathrm{NH}_{2} \mathrm{OH} \mathrm{HCl}\end{array}$ & $(124.1)^{C}$ & 5.3 & 36.4 & - & 38 & 10,000 \\
\hline $\mathrm{Na} \cdot \mathrm{dithionite}$ & & 8.1 & 1.6 & - & - & - \\
\hline Hot $\mathrm{HNO}_{3}$ & $(29.0)$ & 9.4 & - & 530 & - & - \\
\hline $\mathrm{NaHSO}_{4}$ fusion & $(124.4)$ & 4.9 & - & - & - & - \\
\hline Residue = quartz & 300.2 & n.d.d & n.d. & - & n.d. & - \\
\hline Original & 577.7 & & & & ' & \\
\hline $80 \mathrm{C}$ & $(7.0)$ & & & & & \\
\hline $\begin{array}{l}\mathrm{NH}_{4} \text {-acetate, } \\
\mathrm{pH} 7\end{array}$ & & - & - & - & 109 & - \\
\hline $\begin{array}{l}\mathrm{NH}_{4} \text {-citrate, } 2 \% \\
\mathrm{NH}_{2} \mathrm{OH} \mathrm{HCl}\end{array}$ & $(112.3)^{\mathrm{C}}$ & 5.3 & 33.5 & - & 51 & 10,800 \\
\hline Na-dithionite & & 7.7 & 3.8 & - & - & - \\
\hline Hot $\mathrm{HNO}_{3}$ & $(34.4)$ & 10.0 & - & 580 & - & - \\
\hline $\mathrm{NaH}^{\prime} \mathrm{SO}_{4}$ fusion & $(125.2)$ & 4.9 & - & - & - & - \\
\hline Residue $=$ quartz & 298.8 & n.d. & n.d. & - & n.d. & - \\
\hline
\end{tabular}

aOriginal sample had an air-dry weight of $577.7 \mathrm{mg}$ and contained a small amount of organic matter.

$b_{-}=$not detected.

Weight loss after combined treatments.

$d_{n} . d_{.}=$not determined. 
FERROMANGANESE COATING : SEQUENTIIAL DISSOLUTION

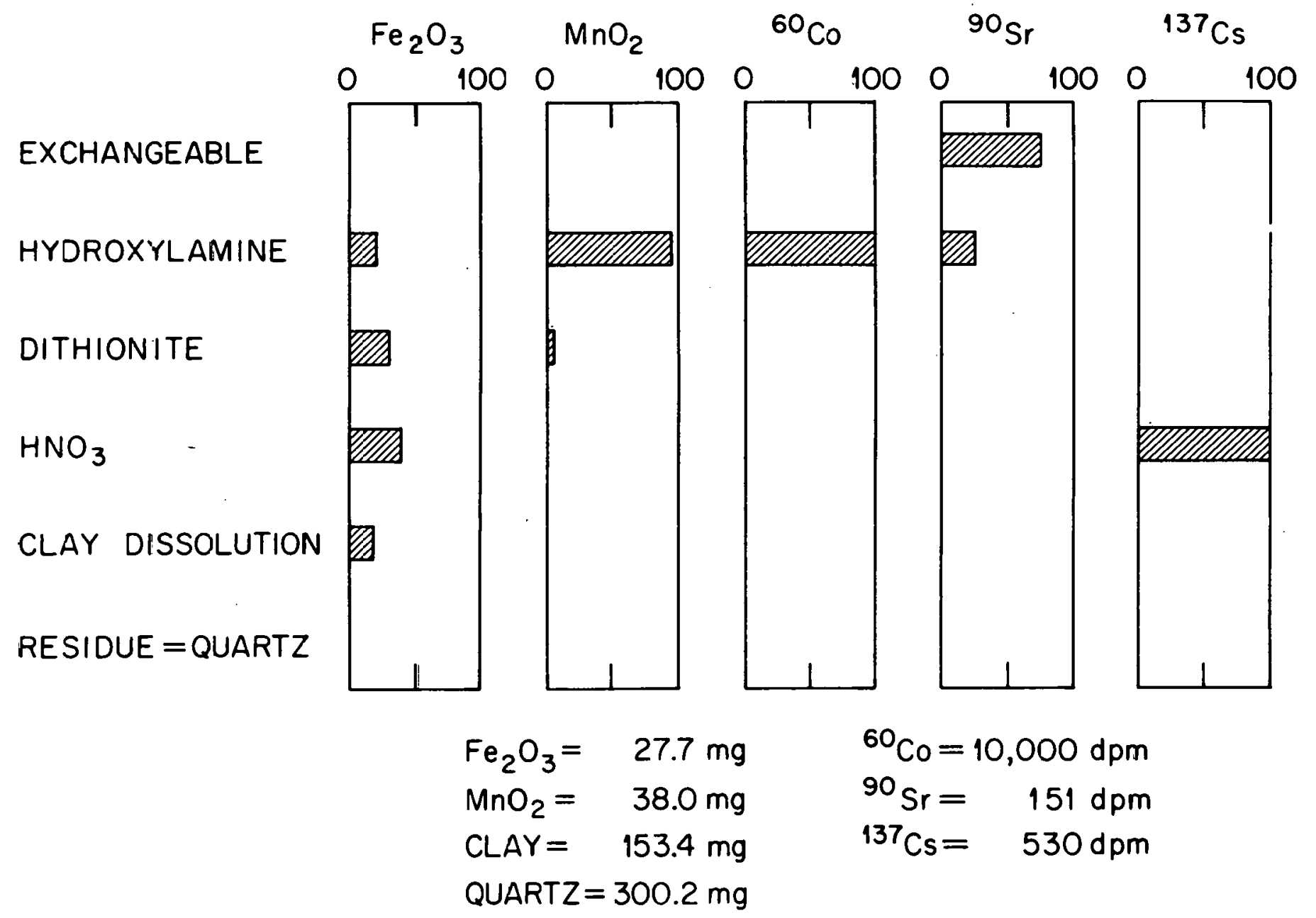

Fig. 3. Percent loss of each component from the manganese oxide-coated shale during sequential dissolution. 
Unlike ${ }^{60} \mathrm{Co}$, the ${ }^{90} \mathrm{Sr}$ in streambed sediment was predominantly in an exchangeable form. Although only $4 \%$ of the sediment ${ }^{90} \mathrm{Sr}$ was soluble in tapwater, about $85 \%$ was exchangeable since it was removed by hot ammonium acetate or sodium chloride (Table 4). Total ${ }^{90} \mathrm{Sr}$ is defined as the amount. extracted by hot $8 \underline{\mathrm{N} \mathrm{HNO}} \mathrm{H}_{3}$. Other extractants were also very effective in removing ${ }^{90} \mathrm{Sr}$ since they all contain exchangeable cations. Notably, ammonium oxalate and sodium dithionite removed considerably less ${ }^{90} \mathrm{Sr}$ than amonium acetate or $\mathrm{NaCl}$; this was likely due to the insolubility of alkaline-earth oxalates and low solubility of $\mathrm{Ca}$ and $\mathrm{Sr}$ sulfates which would form as dithionite is oxidized. A significant portion, about $15 \%$, of the total ${ }^{90} \mathrm{Sr}$ was present in a nonexchangeable form.

Sequential dissolution of both the iron sol and the scraped-off ferromanganese coating showed that greater than $70 \%$ of the ${ }^{90} \mathrm{Sr}$ in each material was exchangeable (Tables 3 and 5; Figs. 3 and 4 ). Hydroxylamine hydrochloride dissolved $90 \%$ of the Mn from the scaped-off ferromanganese coating and all of the remaining, nonexchangeable ${ }^{90} \mathrm{Sr}$ (Table 3 and Fig. 3). The iron sol also lost most of the remaining, nonexchangeable ${ }^{90} \mathrm{Sr}$ during oxidation by $\mathrm{H}_{2} \mathrm{O}_{2}$, followed by extraction with sodium acetate and by reduction with hydroxylamine (Table 5 and Fig. 4); no manganese, however, was detected in these extracts. Interestingly, a small amount of ${ }^{90}$ Sr was strongly held by the clay phases since hot $\mathrm{HNO}_{3}$ and sodium pyrosulfate dissolution of the silicate phases was required to remove it (Table 5).

Several other lines of evidence suggest that the ferromanganese coatings contained ${ }^{90} \mathrm{Sr}$ in a nonexchangeable form. In the 
Table 4. Extraction of $\mathrm{Fe}, \mathrm{Mn},{ }^{90} \mathrm{Sr}$, and ${ }^{137} \mathrm{Cs}$ from coarse sand (3.35 to $\left.0.85 \mathrm{~mm}\right)$ of streambed sediment contaminated with $90 \mathrm{Sr}$ and $137 \mathrm{CS}$

\begin{tabular}{|c|c|c|c|c|c|c|c|c|}
\hline \multirow[b]{2}{*}{ Extraction } & \multicolumn{4}{|c|}{$25^{\circ} \mathrm{C}$} & \multicolumn{4}{|c|}{$95^{\circ} \mathrm{C}$} \\
\hline & $\begin{array}{c}\mathrm{Fe} \\
(\mu \mathrm{g} / \mathrm{g})\end{array}$ & $\begin{array}{c}M n \\
(\mu g / g)\end{array}$ & $\begin{array}{c}{ }^{90} \mathrm{Sr} \\
(\mathrm{dpm} / \mathrm{g})^{\mathrm{b}}\end{array}$ & $\begin{array}{c}137 \mathrm{Cs} \\
(\% \text { total })\end{array}$ & $\begin{array}{c}\mathrm{Fe} \\
(\mu \mathrm{g} / \mathrm{g})\end{array}$ & $\begin{array}{c}M n \\
(\mu g / g)\end{array}$ & $\begin{array}{c}90 \mathrm{Sr} \\
(\mathrm{dpm} / \mathrm{g})^{\mathrm{b}}\end{array}$ & $\begin{array}{l}137 \mathrm{Cs} \\
(\% \text { total })^{a}\end{array}$ \\
\hline Tapwater & 3 & $\leq 10$ & $37(2 \%)$ & 4 & 1 & 10 & $64(4 \%)$ & 2 \\
\hline 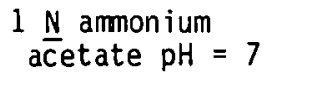 & 6 & 12 & $888(60 \%)$ & 7 & 5 & 39 & $1340(90 \%)$ & 10 \\
\hline $1 \underline{\mathrm{N} \mathrm{NaCl}}$ & 8 & 13 & $789(53 \%)$ & 4 & 6 & 18 & $1210(81 \%)$ & 4 \\
\hline $\begin{array}{l}0.3 \mathrm{M}^{\mathrm{M}} \mathrm{NH}_{4-} \\
\text { citrate }\end{array}$ & 140 & 2000 & $926(62 \%)$ & 5 & 1190 & 3160 & $1350(91 \%)$ & 6 \\
\hline $\begin{array}{l}3 \% \mathrm{H}_{2} \mathrm{O}_{2} \text { in } \\
0.01 \text { M } \mathrm{HNO}_{3}\end{array}$ & 7 & 650 & $316(21 \%)$ & 4 & 6 & 470 & $339(23 \%)$ & 5 \\
\hline $\begin{array}{c}0.1 \frac{\mathrm{M}}{\mathrm{NH}} \mathrm{H}_{2} \mathrm{OH} \cdot \mathrm{HCl} \\
\text { in } 0.01 \underline{\mathrm{M}} \mathrm{HNO}_{3}\end{array}$ & 54 & 2330 & $749(50 \%)$ & 4 & 891 & 3740 & $1260(85 \%)$ & - 6 \\
\hline $\begin{array}{l}2 \% \mathrm{NH}_{2} \mathrm{OH} \cdot \mathrm{HCl} \text { in } \\
0.3 \mathrm{M} \mathrm{NH} 4- \\
\text { citrate, } \mathrm{pH} 7\end{array}$ & 430 & 2920 & $1230(83 \%)$ & 5 & 3060 & 3590 & $1510(101 \%)$ & 7 \\
\hline $\begin{array}{l}0.2 \mathrm{M} \mathrm{NH}_{4-} \\
\text { oxalate } \mathrm{pH} 2\end{array}$ & 920 & 2090 & $38(3 \%)$ & 5 & 6440 & 3460 & $124(8 \%)$ & 7 \\
\hline $\begin{array}{rl}0.2 & \mathrm{~g} / \mathrm{g} \mathrm{Na} \mathrm{N}_{2} \mathrm{O} 4 \\
\text { in } 0.3 \mathrm{Na}-\mathrm{c} \text { itrate } \\
\mathrm{pH} 4.8\end{array}$ & 8220 & 4270 & $906(61 \%)$ & 6 & 11,600 & 3370 & $841 \quad(56 \%)$ & 6 \\
\hline $8 \underline{\mathrm{N}} \mathrm{HNO}_{3}$ & 5670 & 1790 & $1290(89 \%)$ & 29 & 32,900 & 4920 & $1490(100 \%)$ & 49 \\
\hline
\end{tabular}

aTotal ${ }^{137} \mathrm{Cs}$ was $458 \mathrm{dpm} / \mathrm{g}$.

b Total ${ }^{90} \mathrm{Sr}$ is defined as that extracted by hot $8 \underline{\mathrm{N}} \mathrm{HNO}_{3}$. Numbers in parentheses are the percent of the total. 
ORNL- OWG $78-20513 R$

$\mathrm{Fe}_{2} \mathrm{O}_{3}$ SOL : SEQUENTIAL DISSOLUTION

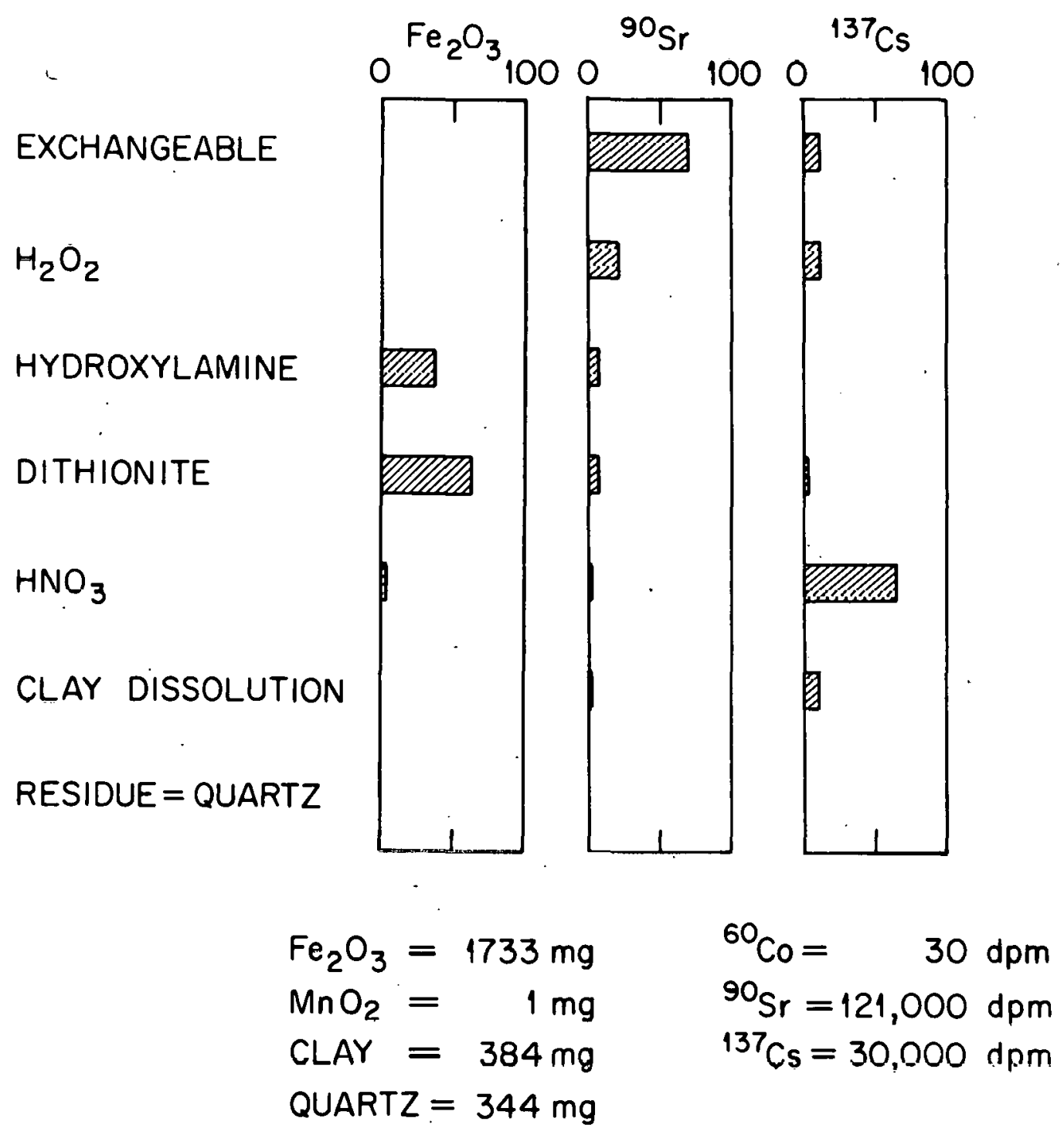

Fig. 4. Percent loss of each component from the Fe sol during sequential dissolution. 
Table 5. Sequential dissolution of an Fe sol collected at a radioactive groundwater seep in SWDA-4

\begin{tabular}{|c|c|c|c|c|c|c|}
\hline Treatment & $\begin{array}{l}\text { Weighta } \\
\text { loss } \\
\text { (mg) }\end{array}$ & $\begin{array}{c}\mathrm{Fe}_{2} \mathrm{O}_{3} \\
(\mathrm{mg})^{\prime}\end{array}$ & $\begin{array}{c}\mathrm{MnO}_{2} \\
(\mathrm{mg}) .\end{array}$ & $\begin{array}{l}137 \mathrm{Cs} \\
(\mathrm{dpm})\end{array}$ & $\begin{array}{r}90 \mathrm{Sr} \\
(\mathrm{dpm})\end{array}$ & $\begin{array}{l}{ }^{60} \mathrm{Co} \\
(\mathrm{dpm})\end{array}$ \\
\hline Water & n.d.b & $-c$ & - & $8.0^{\text {d }}$ & $100^{d}$ & $3.3^{d}$ \\
\hline $1 \underset{\mathrm{pH}}{\mathrm{N}} \mathrm{NH}_{4} \mathrm{NH}_{4}$ acetate & n.d. & 0.3 & 1.3 & 3310 & 84,000 & 30 \\
\hline $\mathrm{H}_{2} \mathrm{O}_{2}$ & n.d. & 1.6 & - & 3150 & 24,000 & - \\
\hline $\begin{array}{l}\mathrm{NH}_{4} \text {-citrate, } 2 \% \\
\mathrm{NH}_{2} \mathrm{OH} \mathrm{HCl}\end{array}$ & n.d. & 656 & - & 440 & 6,000 & - \\
\hline Na-dithionite & n.d. & 1066 & - & 850 & 6,200 & - \\
\hline Hot $\begin{aligned} \mathrm{HNO}_{3}>63 \mu \\
63 \text { to } 2 \mu \\
<2 \mu\end{aligned}$ & $\begin{array}{l}(9.5) \\
(51.6) \mathrm{e} \\
(39.2)\end{array}$ & $\begin{array}{l}0.5 \\
3.1 \\
3.0\end{array}$ & $\begin{array}{l}- \\
-\end{array}$ & $\begin{array}{r}507 \\
5360 \\
13900\end{array}$ & $\begin{array}{l}- \\
62 \\
48\end{array}$ & $\begin{array}{l}- \\
-\end{array}$ \\
\hline $\begin{array}{l}\mathrm{NaHSO}_{4} \\
\text { fusion }>63 \\
63 \text { to } 2 \mu \\
<2 \mu\end{array}$ & $\begin{array}{l}(22.9) \\
(95.2)^{\mathrm{e}} \\
(167.1)\end{array}$ & $\begin{array}{r}0.1 \\
0.9 \\
\cdots \quad 0.9\end{array}$ & 0.1 & 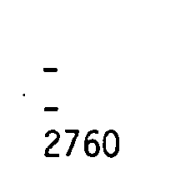 & $\begin{array}{r}- \\
24 \\
188\end{array}$ & $\begin{array}{l}- \\
-\end{array}$ \\
\hline $\begin{aligned} & \text { Residue }= \\
& \text { quartz }>63 \\
& 63 \text { to } 2 \mu \\
&<2 \mu\end{aligned}$ & $\begin{array}{c}142.1 \\
174.2^{\mathrm{e}} \\
27.3\end{array}$ & $\begin{array}{l}\text { n.d. } \\
\text { n.d. } \\
\text { n.d. }\end{array}$ & $\begin{array}{l}\text { n.d. } \\
\text { n.d. } \\
\text { n.d. }\end{array}$ & $\begin{array}{l}- \\
-\end{array}$ & $\begin{array}{l}- \\
-\end{array}$ & $\begin{array}{l}- \\
-\end{array}$ \\
\hline
\end{tabular}

aThe original sample had an oven-dry weight of $3.30 \mathrm{~g}$ and contained some organic matter.

$b_{n . d .}=$ not determined.

$c_{-}=$not detected.

$\mathrm{d}_{\mathrm{Dpm} / \mathrm{ml} \text {. }}$

e Centrifuge tube broke. Extractions carried out on broken tube plus samples. Weights estimated by comparison with another sample. 
non-sequential extractions (Table 4), although about $85 \%$ of ${ }^{90} \mathrm{Sr}$ was exchangeable, all ${ }^{90} \mathrm{Sr}$ was removed by extraction with hydroxylamine in ammonium acetate; this extractant removed most of the Mn but only $10 \%$ of the $\mathrm{Fe}$ extracted by hot $8 \underline{M ~ H N O}_{3}$ (Table 4). Secondly, when a ferromanganese-coated sediment sample was segregated by color into a light and dark fraction, the dark-colored gravel contained $27 \%$ more ${ }^{90} \mathrm{Sr}$ than the lighter-colored gravel (Table 6). The dark-colored gravel contained five times as much $\mathrm{Mn}$ and twice as much Fe extracted by hydroxylamine. than the lighter colored gravel. These separate observations indicate that, although 70 to $85 \%$ of the ${ }^{90} \mathrm{Sr}$ was held in an exchangeable form by streambed gravels and their ferromanganese coatings, most of the remaining, nonexchangeable ${ }^{90} \mathrm{Sr}$ was associated with ferromanganese oxides. Trace amounts were also held in a nonexchangeable form by clay minerals.

Cesium-137, unlike either ${ }^{90} \mathrm{Sr}$ or ${ }^{60} \mathrm{Co}$, could not be extracted in significant amounts (Tables 2 and 4 ) by any solution other than $8 \underline{\mathrm{M} \mathrm{HNO}}{ }_{3}$ which causes structural changes in crystalline minerals. This lack of extractability of ${ }^{137}$ Cs illustrates its strong and specific adsorption by illitic clays (Tamura and Jacobs 1960, Tamura 1963) which compose the parent rock, Conasauga shale, of which this streambed gravel was composed. Dark-colored gravel from a spi it sample contained approximately five times as much ${ }^{137} \mathrm{Cs}$ and $\mathrm{Mn}$ as did the light-colored gravel (Table 6). Progressive dissolution of the scraped-off ferromanganese coating showed that all the ${ }^{137} \mathrm{Cs}$ was associated with illite since the ${ }^{137}$ Cs was not dissolved until treatment with $8 \underline{\mathrm{M}} \mathrm{HNO}_{3}$ (Table 3 and Fig. 3 ). Dissolution of the 
Table 6. Radionuclide and extractable Fe and Mn content of s.treambed gravel ( 4.75 to $2.0 \mathrm{~mm}$ ) segregated by color

\begin{tabular}{lcc}
\hline & $\begin{array}{c}\text { Light-colored } \\
\text { gravel }\end{array}$ & $\begin{array}{c}\text { Dark-colored } \\
\text { gravel }\end{array}$ \\
\hline $137 \mathrm{Cs}(\mathrm{dpm} / \mathrm{g})^{\mathrm{a}}$ & 54 & 266 \\
$90 \mathrm{Sr}(\mathrm{dpm} / \mathrm{g})^{\mathrm{b}}$ & 1025 & 1300 \\
$60 \mathrm{Co}(\mathrm{dpm} / \mathrm{g})^{\mathrm{a}}$ & 6.0 & 20.0 \\
$\mathrm{Mn}(\mu \mathrm{g} / \mathrm{g})^{\mathrm{b}}$ & 910 & 4630 \\
$\mathrm{Fe}(\mu \mathrm{g} / \mathrm{g})^{\mathrm{b}}$ & 1220 & 2940 \\
\hline
\end{tabular}

aTotal content based on triplicate 10-g samples.

bextractable in $2 \%$ hydroxylamine hydrochloride/0.3 M ammonium citrate, pH 7, based on triplicate $10-\mathrm{g}$ samples. 
iron sol was less straightforward (Table 5 and Fig. 4). Although most of the ${ }^{137} \mathrm{Cs}$ was released by $8 \underline{\mathrm{M}} \mathrm{HNO}_{3}$ or by treatment to remove the layer silicates, significant amounts were present in the water associated with the seep or removed by ammonium acetate or $\mathrm{H}_{2} \mathrm{O}_{2}$ extraction. The high concentration of ${ }^{137} \mathrm{Cs}$ in the water likely indicates that the adsorption capacity of the small amount of clay in this sample may have been exceeded. The calculated $K_{d}$ of ${ }^{137} \mathrm{Cs}$ for this sample and its associated water was about 10,000.

These studies have shown which mineral phases are responsible for the adsorption of each radionuclide by streambed sediment. They also give some indication of how each radionuclide is likely to move in the stream. Because ${ }^{60}$ Co was found to be strongly associated with the ferromanganese oxide phase, it is likely to be solubilized by stream water as sediment moves from well-aerated to reducing sections of a particular stream. The ferromanganese hydrous oxide cuatings on streambed sediments undergo deposition or dissolution, depending on the Eh of the stream water (Jenne 1968). Cobalt-60 is, therefore, likely to move in streams as Mn does.

Cesium-137 was also restricted almost entirely to a single phase. Even the ferromanganese-coated sample had all of its ${ }^{137} \mathrm{Cs}$ associated with the layer silicate phase; most of ${ }^{137} \mathrm{Cs}$ in the iron sol was also associated with the layer silicate phase. Cesium-137 content was also five times greater in dark-colored streambed gravel than in the portion of the same sample which was lighter-colored (Table 6 ). These results suggest that ${ }^{137} \mathrm{Cs}-\mathrm{clay}$ particles may be incorporated into growing ferromanganese coatings. The ferromanganese coating contained less 
than $10 \%$ Mn plus $\mathrm{Fe}$; the remainder was original rock, detrital minerals, and, possibly, organic matter. Examination of an apparently homogeneous ferromanganese coating with an electron microprobe (10- $\mu$ beam diam.) showed a maximum of $42 \% \mathrm{MnO}_{2}$ and $14 \% \mathrm{Fe}_{2} \mathrm{O}_{3}$, with minor amounts of $\mathrm{Si}, \mathrm{Al}, \mathrm{K}, \mathrm{Ca}, \mathrm{Ni}$, and $\mathrm{Cu}$ indicating the presence of silicate inclusions as well as other metals.

Strontium-90 occurred primarily as an exchangeable cation in streambed sediment, although it is uncertain which of the three dominant phases ( $\mathrm{Clay}, \mathrm{\delta}-\mathrm{MnO}_{2}$ or $\mathrm{Fe}-\mathrm{sol}$ ) was most important. Iron and Mn hydrous oxides have a significant capacity to adsorb cations (Kinniburgh et al. 1976, Loganathan et al. 1977) and several common manganese minerals contain alkaline earth elements (McKenzie 1977). Although some ${ }^{90} \mathrm{Sr}$ is likely in a nonexchangeable form, most ${ }^{90} \mathrm{Sr}$ is likely partitioned between the stream water and sediment by a cation exchange mechanism probably maintained by the level of dissolved $\mathrm{Ca}$ in stream-water.

\section{ADSORPTION OF ${ }^{85} \mathrm{Sr}$ TO STREAMBED MATERIALS}

As noted above, several different materials have cation exchange sites available for strontium. In order to estimate the relative importance of each of these materials in radionuclide contamination, distribution coefficients for trace levels of strontium were determined for bedrock materials, various kinds of organic matter, and iron and manganese hydrous oxides. Samples of streambed gravel were collected on March 20 and 21, 1978, as part of a preliminary survey of White 0ak Creek sediment for radionuclide contamination. From this collection, 
several samples were selected that had differing lithologies: brown shale, dark shale with ferromanganese coating, light-colored chert, limestone, chert-limestone-shale mixture, and dark chert with ferromanganese coating. Samples of organic material were collected from White Oak Creek upstream (northeast) of the ORNL plant site.

\section{Experimental}

\section{Lithologic Materials}

One milliliter of carrier-free ${ }^{85} \mathrm{Sr}(138,000 \mathrm{dpm})$ was added to $25 \mathrm{ml}$ of freshly collected creek water ( $\mathrm{pH} \mathrm{7.3,} \mathrm{e.c.} 96 \mu \mathrm{mhos} / \mathrm{cm}$ ) containing $10.0 \mathrm{~g}$ of oven-dried gravel-sand in a 50-ml polypropylene centrifuge tube. The tube was shaken lengthwise for $18 \mathrm{hr}$ at room temperature and centrifuged at 650 RCF for $10 \mathrm{~min}$ on an IEC model PR-2 refrigerated centrifuge. A $10-\mathrm{ml}$ aliquot of the supernatant was transferred to a 30-ml polycarbonate "0ak Ridge"-type centrifuge tube and centrifuged for 15 min al 36,000 RCF with a Beckman L-2 ultracentrifuge (equipped with a No. 30 head) to remove suspended material not removed during the initial centrifugation at lower speed. A 5-ml aliquot of the supernatant was transferred to a $25-\times 150-\mathrm{mm}$ test tube and counted on a Packard Model 16 multichannel analyzer using $30,000 \mathrm{dpm}$ of ${ }^{85} \mathrm{Sr}$ in $5 \mathrm{ml}$ of water as a standard; activity of the standard was determined by the Analytical Chemistry Division. All observations were corrected for radioactive decay from the time of calibration. Background counts in the ${ }^{85} \mathrm{Sr}$ channels window were obtained with empty test tubes. The amount of ${ }^{85} \mathrm{Sr}$ adsorbed by a sample was determined by calculating the difference in the concentration 
in the supernatant of a sample and that of a control containing no gravel. The concentration of ${ }^{85} \mathrm{Sr}$ in the creek water was determined directly from the counts of the $5 \mathrm{ml}$ of supernatant. The average $k_{d}$ from duplicate determinations was calculated by the ratio of $\mathrm{dpm} / \mathrm{g}$ of solids to $\mathrm{dpm} / \mathrm{ml}$ of supernatant.

\section{Organic Materials}

Samples of organic materials common to streambeds were collected from White Oak Creek, upstream (northeast) of the ORNL plant site. These included a sound wood branch, a somewhat darkened/rotted wood branch, a well-rotted wood branch, partially discolored deciduous leaves, dark-colored/well-rotted leaves, and a green algal slime. The material was oven-dried $\left(100^{\circ} \mathrm{C}\right.$, overnight) and ground in a Wiley mill to pass a $2-\mathrm{mm}$ sieve. Duplicate samples $(2.50 \mathrm{~g})$ of each type were shaken with $35 \mathrm{ml}$ of freshly collected creek water $(\mathrm{pH} 7.7$, electrical conductivity of $196 \mu$ mhos $/ \mathrm{cm}$ ) to which was added $109,000 \mathrm{dpm}$ of ${ }^{85} \mathrm{Sr}$ in $1 \mathrm{ml}$ of water. The average $K_{d}$ for each material was calculated after counting supernatants, as described above. A second $K_{d}$ determination for these same organic materials was performed after twice washing the samples with water. Duplicate 1-g samples were weighed into tared 50-m1 polypropylene centrifuge tubes. Forty miliiliters of freshly collected creek water ( $\mathrm{pH} \% .7$, electrical conductivity of 196 mhos $/ \mathrm{cm}$ ) were added and the tubes capped and shaken lengthwise for $48 \mathrm{hr}$. The tubes were centrifuged for $15 \mathrm{~min}$ at 650 RCF on the IEC Model PR-2 centrifuge and the supernatants discarded; a second wash was carried out with $30 \mathrm{ml}$ of creek water with 
shaking for $4 \mathrm{hr}$, centrifuging, and decanting as before. The tubes were weighed to determine the amount of adsorbed water and additional creek water added to attain $30 \mathrm{ml}$ per tube. One milliliter of water containing $97,000 \mathrm{dpm}$ of ${ }^{85} \mathrm{Sr}$ was added and the contents shaken lengthwise for $16 \mathrm{hr}$. The $\mathrm{K}_{d}$ was then calculated as described above.

\section{Synthetic Iron and Manganese Hydrous Oxide}

Artificial $\delta-\mathrm{MnO}_{2}$ and iron hydrous oxides were prepared by the oxidation of a $\mathrm{MnCl}_{2}-\mathrm{NaOH}$ mixture at $\mathrm{pH} 8$ to 12 (similar to the method of Jeffries and Stumm 1976) and by neutralization of $\mathrm{Fe}\left(\mathrm{NO}_{3}\right)_{3}$ by $\mathrm{NaOH}$ (Kinniburgh et al. 1975) to $\mathrm{pH} 7$, respectively. After formation of the hydrous oxides, excess salts were removed by repeated washings with distilled water and centrifugings at 600 RCF for 20 min until the hydrous oxide began to destabilize. The hydrous oxide was then air-dried. Twenty milliliters of White 0ak Creek water (pH 7.7, electrical conductivity of $196 \mu$ mhos $/ \mathrm{cm}$ ) were added to 50 to $100 \mathrm{mg}$ of air-dried gel; ${ }^{85} \mathrm{Sr}(86,000 \mathrm{dpm})$ was added to each sample. Samples were then shaken continuously for $24 \mathrm{hr}$ and analyzed as described above.

A second set of hydrous oxides was prepared by the oxidation or neutralization of aliquots containing a known amount of manganese or iron $(50$ to $100 \mathrm{mg}$ ). These samples were treated as above except that the air drying step was omitted to minimize structural changes due to drying. The amounts of manganese or iron hydrous oxide in these samples were checked for loss by filtering blank precipitates through tared fritted-glass crucibles. Oven-dried $\left(110^{\circ} \mathrm{C}\right)$ sols weighed within 
$5 \%$ of the amount of $\mathrm{MnO}_{2}$ or $\mathrm{Fe}_{2} \mathrm{O}_{3}$ in the aliquot, indicating that loss was minimal.

\section{Results and Discussion}

Table 7 demonstrates that Conasauga shale had a six- to sevenfold greater $K_{d}$ for ${ }^{85} S r$ than chert and a tenfold greater $K_{d}$ than 1 imestone. Notably a ferromanganese hydrous oxide-coated shale (dark-colored) exhibited a $12 \%$ greater $\mathrm{K}_{d}$ for ${ }^{85} \mathrm{Sr}$ than an uncoated (light-colored) shale. Rotted wood and leaves exhibited an affinity for ${ }^{85} \mathrm{Sr}$ similar to Conasauga shale (Table 7). Oven-drying of wood and leaves leads to a release of some soluble organic matter (Jenkinson 1966), and it was suspected that this might increase the ionic strength of the stream water that was used for the $k_{d}$ determination, and hence, lead to an unrealistically low $k_{d}$. The equilibrium supernatant from the unwashed, oven-dried organic materials appeared highly colored; twice prewashing these organic materials with creek water removed most of the color and in some cases, the observed $K_{d}{ }^{\prime} s$ rose considerabiy. The $K_{d}$ 's determined with the prewashed organic materials likely reflect their affinities for ${ }^{90} \mathrm{Sr}$ in the unperturbed (non-oven-dried) state.

Several $K_{d}$ 's were determined for natural and synthetic iron hydrous oxides and $\delta-\mathrm{MnO}_{2}$. These $\mathrm{K}_{d}$ 's were quite variable and probably were related to the degree of crystallinity of the specimens. Burns (1976) suggested that the adsorbtion of cations should decrease as the amount of birnessite (crystalline $\delta-\mathrm{MnO}_{2}$ ) increases. In addition, the adsorption capacity of both iron sols and $\mathrm{\delta}_{1}-\mathrm{MnO}_{2}$ 
Table 7. Distribution coefficient $\left(K_{d}\right)$ of 85 sir between white 0ak Creek water and streambed gravels, sediments, organic matter and $\mathrm{Fe}-\mathrm{Mn}$ oxides

\begin{tabular}{|c|c|c|c|}
\hline Gravels & Sample number & $k_{d}{ }^{a}$ & \\
\hline $\begin{array}{l}\text { Light-colored shale } \\
\text { Dark-colored shale } \\
\text { Light-colored chert } \\
\text { Mixed chert and limestone } \\
\text { Mixed chert and limestone } \\
\text { Limestone }\end{array}$ & $\begin{array}{r}9-7 \\
9-8 \\
9-14 \\
9-18 \\
9-19 \\
9-21\end{array}$ & $\begin{array}{r}129 \\
144 \\
20 \\
23 \\
8 \\
6\end{array}$ & $\begin{array}{l}b \\
b \\
b \\
b \\
b \\
b\end{array}$ \\
\hline Organic material & $K_{d}$ (unwashed) $d$ & $K_{d}$ (washed) & \\
\hline $\begin{array}{l}\text { Wood, light-colored (sound) } \\
\text { Wood, dark-colored (rotted) } \\
\text { Wood, very dark (rotted) } \\
\text { Deciduous leaves: dark, } \\
\text { slightly decomposed } \\
\text { Deciduous leaves: very dark, } \\
\text { slight ly dccomposed } \\
\text { Algal slime }\end{array}$ & $\begin{array}{r}49 \\
102 \\
78 \\
\\
127\end{array}$ & $\begin{array}{r}60 \\
144 \\
155 \\
\\
392\end{array}$ & $\begin{array}{l}\mathrm{C} \\
\mathrm{C} \\
\mathrm{c}\end{array}$ \\
\hline
\end{tabular}

Fe-Mn oxides

$K_{d}$

$\mathrm{Fe}_{2} \mathrm{O}_{3}$-sol (natural)

$\mathrm{Fe}_{2} \mathrm{O}_{3}$-sol (synthetic)

$\delta-\mathrm{MnO}_{2}$ natural

$\delta-\mathrm{MnO}_{2}$ synthetic

550

150

100 to $>1000$

100 to $>1000$

c

c

c

c

$a_{K_{d}}=\frac{d p m / g \text { solid }}{d p m / m 1 \text { creek water }}$.

b creek water of $\mathrm{pH} 7.3, \varepsilon=96 \mu \mathrm{mhos} / \mathrm{cm}$.

${ }^{c}$ Creek water of $\mathrm{pH} 7.7, \varepsilon=196 \mu \mathrm{mhos} / \mathrm{cm}$.

dPrewashed samples rinsed twice with this creek water before $K_{d}$ determinations (see text). 
changes most rapidly in the pH range of 6 to 9 (Kinniburgh et al. 1975, Loganathan et al. 1977) which includes the $\mathrm{pH}(7-8)$ of the stream water used for these $\mathrm{K}_{\mathrm{d}}$ determinations. Thus, small changes in $\mathrm{pH}$ due to aging of the gel could lead to marked changes in the measured $K_{d}$ 's.

\section{OPTIMUM SIZE FOR SEDIMENT SAMPLING}

Iron and manganese concentrations are not uniformly distributed with respect to the size of sediments (Whitney 1975). Because of mineralogical differences between different size fractions, it is expected that the radionuclides will not be uniformly distributed either. Furthermore, it would be useful to sample a size that is easily reproducible, one that can be done in the field, and one that is present in large amounts at most sites. For these reasons, the distribution of radionuclides with respect to size fraction was determined.

\section{Experimental}

On March 1, 1978, a ldarye (approximately $3.5-\mathrm{kg}$ ) sample of sediment was collected to a 4-cm depth from the channel of the tributary of white 0ak Creek that runs south of SWDA-4. The sample was sieved under a flow of tapwater into seven size fractions; clay and silt fractions were isolated by gravity or centrifugal sedimentation (Jackson 1956). All gravitational and centrifugal size isolates were washed three to five times by resuspending in tapwater until the final 
supernatant appeared clear; all supernatants were combined and used for the isolation of the next smaller size fraction. Each fraction was oven-dried $\left(105^{\circ} \mathrm{C}\right.$, overnight) and weighed.

Each size fraction was analyzed for ${ }^{137} \mathrm{Cs}$ content before and after extraction with $2 \%$ hydroxylamine hydrochloride/0.3 $\mathrm{M}$ ammonium citrate, $\mathrm{pH} 7.0$, as described previously. The ${ }^{90} \mathrm{Sr}, \mathrm{Mn}$, and $\mathrm{Fe}$ contents were also determined on these extracts as described previnusly. The ${ }^{60}$ Co content of each fraction (except the coarse-silt and all clay fractions which were expended) was also determined as described previously. The quartz contents were estimated by comparing quartz $X$-ray diffraction peak heights $(100)$ in each size fraction with that in artificial quartz-illite mixtures. Standards and samples were ground to pass a 325 -mesh sieve and mounted in reversible glass-backed aluminum frames. Each standard was run three times to prepare a calibration curve; unknowns were also run three times and the average peak height was used to estimate the quartz percentage. A Philip's X-ray diffractometer with a Ni-filtered Cu-K radiation source operating at $40 \mathrm{kv}$ and $20 \mathrm{ma}$ with a scanning speed of $1 \% / \mathrm{min}$ was used for these studies.

\section{Results and Discussion}

The distribution of ${ }^{137} \mathrm{Cs},{ }^{90} \mathrm{Sr}, \mathrm{Fe}$, and $\mathrm{Mn}$ in size-fractionated sediment further illustrates associations between radionuclides and mineral phases (Fig. 5). Both ${ }^{90} \mathrm{Sr}$ and ${ }^{137} \mathrm{Cs}$ concentrations were bimodal in this sediment, with maxima in the fine gravel to coarse sand $(-2$ to $+2 \phi)$ and again in the medium-silt to clay 

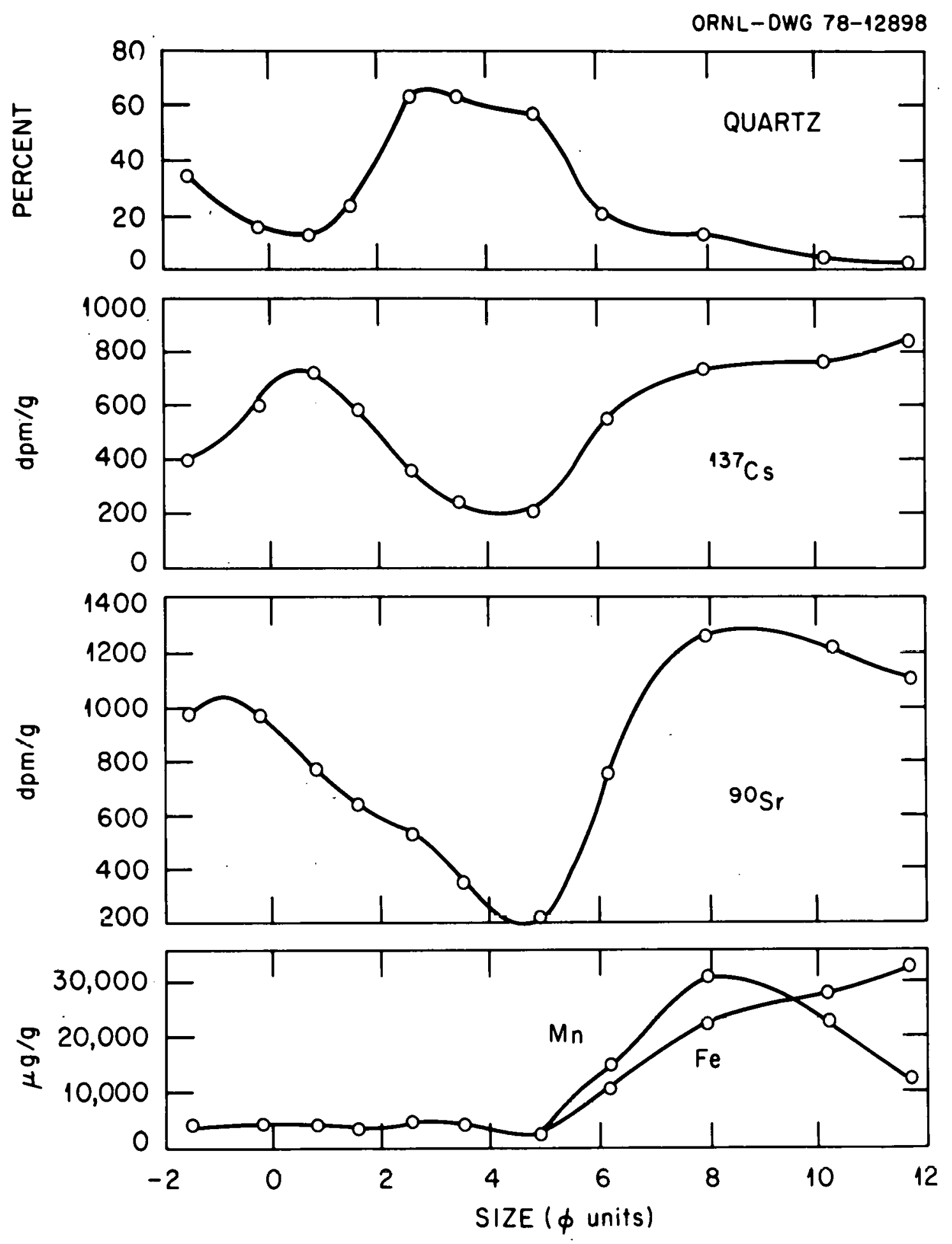

Fig. 5. The distribution of quartz, $137 \mathrm{Cs}$, and $90 \mathrm{Sr}, \mathrm{Mn}$, and Fe extractable by hydroxylamine in size fractions of contaminated streambed sediment. 
fractions ( 7 to $9 \phi)$. Cobalt-60, although present at only low levels in this sample, also exhibited a maximum in the coarse-sand fraction (Table 8) and appeared to be increasing again from the coarse- to medium-silt-sized fractions; unfortunately, the finer-sized fractions were not available for ${ }^{60}$ Co analyses. Since the size isolates larger than medium sand represented greater than $95 \%$ of whole sample weight (Table 8 ), most of the total radioactivity was associated with these larger fractions; such 1 arger-sized fractions would also have a much lower potential than the finer sizes for transport in the stream as suspended solids. Thus, the coarser fractions will have a longer residence time in a given stream section and their radionuclide content likely represents prolonged contact with stream water within that stream section. Ideally, a stationary fraction, such as exposed. bedrock, could be chosen but this is rarely possible. Thus, the fine-grave 1 to coarse-sand fraction appears to be the best size fraction for monitoring radionuclide contamination by ${ }^{60} \mathrm{Co},{ }^{90} \mathrm{~S} \dot{r}$, and ${ }^{137} \mathrm{Cs}$ of streambed sediments because of its abundance in the sediment, its ease in isolating and sampling, and its high concentrations of the radionuclides of interest. In addition, gravels/sands with ferromanganese hydrous oxide coatings represent those sediments which have been deposited for some time and, hence, would have more abundant sites for radionuclide retention. These coated sediments generally occur in riffles in the streams.

The bimodal distribution of each radionuclide was strongly related to the mineralogical composition of each size fraction. Quartz, with its comparatively inert surface, would not be expected to adsorb 
Table 8. Radionuclide and extractable $\mathrm{Fe}$ and Mn of streambed sediment size fractions

\begin{tabular}{|c|c|c|c|c|c|c|c|c|c|c|}
\hline \multirow[b]{2}{*}{ Name } & \multicolumn{9}{|c|}{ Size fraction } & \multirow[b]{2}{*}{ Notes } \\
\hline & $\begin{array}{l}\text { Range } \\
(\mu)\end{array}$ & $\begin{array}{l}\text { Mean size } \\
(\phi)\end{array}$ & $\begin{array}{l}\text { Weight } \\
(\mathrm{g})\end{array}$ & $\begin{array}{c}M n^{d} \\
(\mu g / g)\end{array}$ & $\begin{array}{c}\mathrm{Fe}^{\mathrm{a}} \\
(\mu \mathrm{g} / \mathrm{g})\end{array}$ & $\begin{array}{c}{ }^{90} \mathrm{Sr}_{\mathrm{a}}^{\mathrm{a}} \\
(\mathrm{dpm} / \mathrm{g})\end{array}$ & $\begin{array}{l}{ }^{137} \mathrm{Cs}^{\mathrm{b}} \\
(\mathrm{dpm} / \mathrm{g})\end{array}$ & $\begin{array}{c}{ }^{60} \mathrm{Co}^{\mathrm{b}} \\
(\mathrm{dpm} / \mathrm{g})\end{array}$ & $\begin{array}{c}\text { Quartz } \\
(\%)\end{array}$ & \\
\hline $\begin{array}{l}\text { Coarse gravel } \\
\text { Fine gravel } \\
\text { Very coarse sand } \\
\text { Coarse sand } \\
\text { Medium sand } \\
\text { Fine sand } \\
\text { Very fine sand } \\
\text { Coarse silt } \\
\text { Medium silt } \\
\text { Fine silt } \\
\text { Coarse clay } \\
\text { Medium clay } \\
\text { Fine clayj }\end{array}$ & $\begin{array}{c}40,000-4750 \\
4,750-2000 \\
2,000-850 \\
850-500 \\
500-212 \\
212-125 \\
125-88 \\
88-20 \\
20-12 \\
12-2 \\
2-0.5 \\
0.5-0.2 \\
\leq 0.2\end{array}$ & $\begin{array}{r}-3.79 \\
-1.63 \\
-0.39 \\
+0.62 \\
1.62 \\
2.62 \\
3.26 \\
4.58 \\
6.01 \\
7.68 \\
9.97 \\
11.63 \\
\geq 12.29\end{array}$ & $\begin{array}{r}2200.0 \\
741.8 \\
325.1 \\
100.6 \\
58.2 \\
19.1 \\
17.8 \\
10.9 \\
31.2 \\
19.4 \\
0.2 \\
1.6 \\
1.0\end{array}$ & $\begin{array}{r}2700 \\
4130 \\
4770 \\
4170 \\
3760 \\
4920 \\
4310 \\
2140 \\
15700 \\
31900 \\
23800 \\
13000 \\
4210\end{array}$ & $\begin{array}{r}2110 \\
4070 \\
4220 \\
3500 \\
3600 \\
5270 \\
3970 \\
2240 \\
11300 \\
23200 \\
28800 \\
33900 \\
27400\end{array}$ & $\begin{array}{r}539 \\
996 \\
942 \\
776 \\
653 \\
547 \\
366 \\
216 \\
764 \\
1276 \\
1228 \\
1123 \\
408\end{array}$ & $\begin{array}{l}\text { n.d.c } \\
388 \\
583 \\
709 \\
568 \\
348 \\
240 \\
214 \\
550 \\
732 \\
758 \\
846 \\
675\end{array}$ & $\begin{array}{l}\text { n.d. } \\
13 \\
26 \\
30 \\
29 \\
26 \\
18 \\
\text { n.d. } \\
54 \\
88 \\
\text { n.d. } \\
\text { n.d. } \\
\text { n.d. }\end{array}$ & $\begin{array}{l}\text { n.d. } \\
33 \\
16 \\
13 \\
24 \\
63 \\
63 \\
58 \\
20 \\
13 \\
4 \\
-h \\
-\end{array}$ & $\begin{array}{l}d \\
d \\
d \\
d \\
d \\
e \\
e \\
f \\
f \\
f \\
g \\
i \\
k\end{array}$ \\
\hline
\end{tabular}

a Extracted in $2 \% \mathrm{NH}_{\mathrm{C}} \mathrm{OH} \cdot \mathrm{HCl} / 0.3 \mathrm{M}$ ammonium citrate, pH 7.

${ }^{\mathrm{b}}$ Total.

$c_{n \cdot d .}=$ not determined.

driplicate 10-3 samples used for extraction and counting.

ETriplicate $5-g$ samples.

fouplicate $5-g$ samples.

${ }^{9}$ Single 5 -g sample.

$\mathrm{h}_{-}=$not detected.

${ }^{i}$ Single $1-g$ sample.

jSettled solids $24 \mathrm{hr}$ after flocculation with $50 \mathrm{ml}$ of $1 \mathrm{M} \mathrm{CaCl}_{2}$ in 8 liter of combined rinse water from previous size isolate.

$k_{\text {Single } 0.95-g \text { sample. }}$ 
radionuclides. Notably its concentration reached a maximum in the fine sand to coarse silt fractions exactly where ${ }^{90} \mathrm{Sr}$ and ${ }^{137} \mathrm{Cs}$ concentrations on the sediment attained minima. The larger-sized fractions were dominated by shale fragments, i.e., aggregated clay and other minerals, with considerable ferromanganese hydrous oxide coatings; quartz exists as sand-and silt-sized grains in the shale fragments of the coarser sizes. Quartz is the dominant mineral in the medium-sand to coarse-silt fraction, while clay minerals dominate in the smaller fractions. This large increase in ferromanganese coatings in the clay-sized fractions was probably due to the large increase in surface area per unit weight with decreasing particle size.

The distribution of radionuclides and mineralogical composition with sediment size will differ when other rock types dominate the sediment. However, Conasauga shale is the dominant parent rock in Melton Valley where, presumably, most radionuclide contamination arises. Other types of rocks including chert, dolomite, and 11mestorle enter White Oak Creek in Bethal Valley and are transported into Melton Valley by the creek.

\section{SURVEY OF WHITE OAK CREEK STREAMBED SEDIMENTS}

Samples of streambed sedimenl were collected from all major streams and tributaries in the White 0ak Creek drainage basin on several dates in March and April 1978. Figure 1 shows the location of the solid waste disposal areas (SWDA) and intermediate-level liquid waste (ILLW) pits and trenches within the White Oak Creek basin; Fig. 6 shows the location of sampling sites with respect to these references 


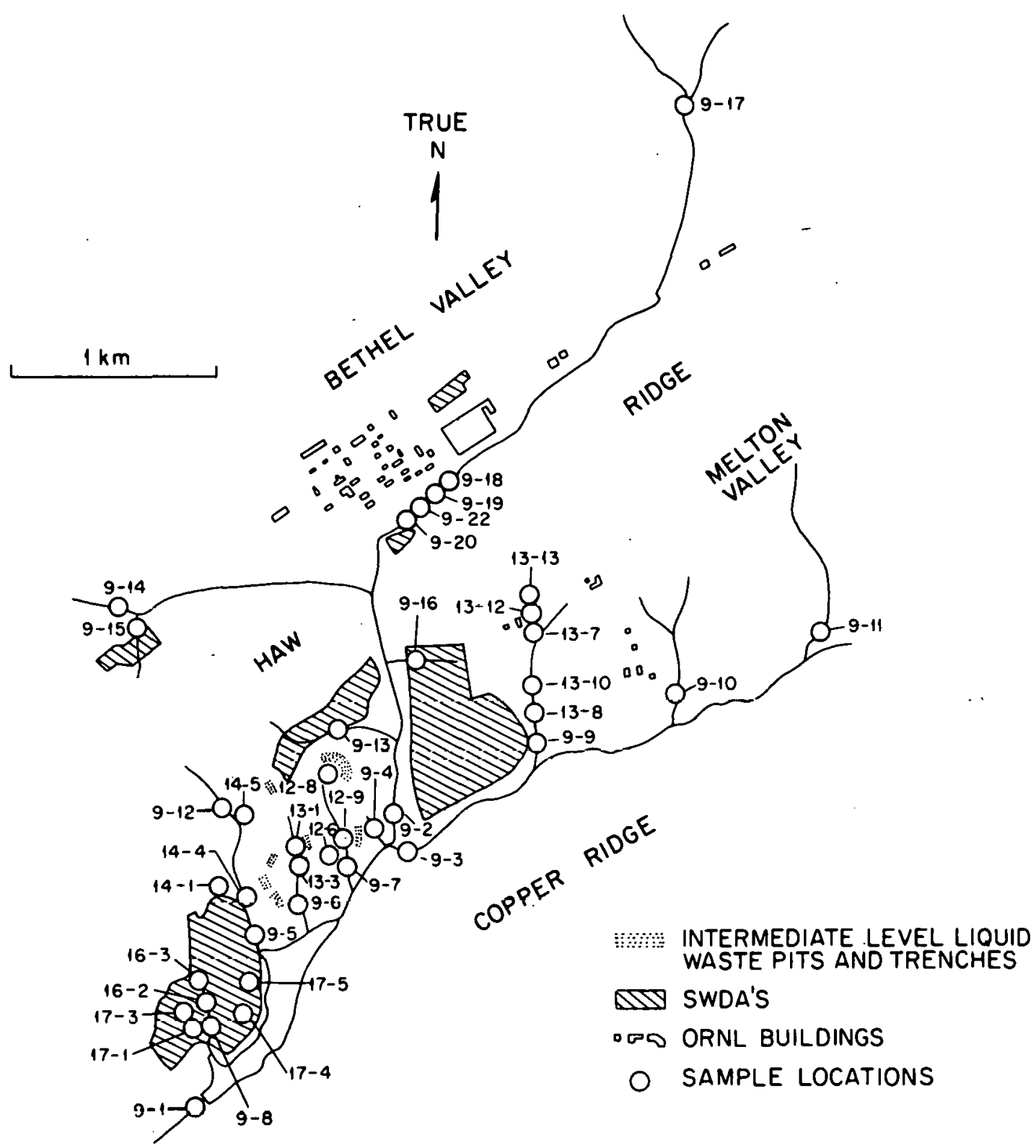

Fig. 6. Location of streambed sediment samples from White 0ak Creek watershed. Sample ident ification numbers correspond to the radiochemical concentrations listed in Table 6. 
and ORNL buildings. Samples were collected from sections of streams where ferromanganese oxide-coated gravel deposits appeared to dominate the surface of the streambed sediment; generally, these areas are narrower and more rapidly flowing sections of a given stream. Samples were collected to a depth of approximately $4 \mathrm{~cm}$ and placed in polyethylene seal-lock bags. The material was sieved under flowing tapwater and the fine-gravel and coarse-sand fraction ( 3.35 to $0.85 \mathrm{~mm}$ ) isolated and oven-dried $\left(105^{\circ} \mathrm{C}\right.$, overnight). The ${ }^{60} \mathrm{Co}$ and ${ }^{137} \mathrm{Cs}$ content of a $10 \mathrm{-g}$ sample was determined as described previously. The exchangeable ${ }^{90} \mathrm{Sr}$ content was determined using the hot $1 \underline{N}$ ammonium acetate, $\mathrm{pH} 7$, extracting procedure described previously.

The observed radionuclide content of each sample is listed in Table 9. To summarize the distribution in the watershed, a graphical representation of each radionuclide's distribution is presented in Figs. $7\left({ }^{90} \mathrm{Sr}\right), 8\left({ }^{137} \mathrm{Cs}\right)$, and $9\left({ }^{60} \mathrm{Co}\right)$.

Several generalizations concerning the origin and distribution of each radionuclide can be made. First, the headwater sediments of each stream were at or near background levels of radioactivity of each radionuclide. Strontium-90 appeared to have several major origins including SWDA-4, SWDA-5, ORNL plant effluents, the stream draining the western half of SWDA-6, ILLW trench 6, and ILLW pit 1 (samples 9-13, 13-10, 9-19, 16-2, 12-8, and 14-5, respectively). Cesium-137 seemed to be distributed similarly to ${ }^{90} \mathrm{Sr}$ but did not appear in SWDA-6 or ILLW pit 1 drainage; additional low contamination (41 and $26 \mathrm{dpm} / \mathrm{g}$ ) was observed in the sediment of streams draining SWDA-3 (sample 9-15) and the high flux isotope reactor complex (sample 9-10), respectively. 
Table 9. Radionuclide concentrations of streambed sediment samples of White Oak Creek watershed

\begin{tabular}{|c|c|c|c|}
\hline Sample No. & $\begin{array}{l}\text { Total } 137 C s \\
(d p m / g)\end{array}$ & $\begin{array}{l}\text { Total }{ }^{60} \mathrm{Co} \\
(\mathrm{dpm} / \mathrm{g})\end{array}$ & $\begin{array}{c}\text { Exchangeable } \\
\qquad(\mathrm{dpm} / \mathrm{g})\end{array}$ \\
\hline $\begin{array}{l}9-1 \\
9-2 \\
9-3 \\
9-4 \\
9-5 \\
9-6 \\
9-7 \\
9-8 \\
9-9 \\
9-10 \\
9-11 \\
9-12 \\
9-13 \\
9-14 \\
9-15 \\
9-16 \\
9-17 \\
9-18 \\
9-19 \\
9-20 \\
9-22 \\
12-6 \\
12-8 \\
12-9 \\
13-3 \\
13-7 \\
13-8 \\
13-10 \\
13-12 \\
13-13 \\
14-1 \\
14-4 \\
14-5 \\
16-2 \\
16-3 \\
17-1 \\
17-3 \\
17-4 \\
17-5\end{array}$ & $\begin{array}{c}969 \\
3350 \\
57 \\
-a \\
11 \\
- \\
25 \\
- \\
3331 \\
26 \\
- \\
- \\
246 \\
- \\
41 \\
- \\
- \\
9 \\
164 \\
1108 \\
3409 \\
8 \\
136 \\
62 \\
5 \\
95 \\
893 \\
1570 \\
9 \\
- \\
- \\
9 \\
4 \\
- \\
- \\
- \\
- \\
- \\
-\end{array}$ & $\begin{array}{r}139 \\
203 \\
119 \\
10,220 \\
541 \\
1,053 \\
170 \\
3 \\
8 \\
1199 \\
4 \\
2 \\
21 \\
-\quad \\
3 \\
4 \\
-\quad \\
3 \\
47 \\
42 \\
554 \\
335 \\
38 \\
370 \\
440 \\
180 \\
3 \\
7 \\
104 \\
3 \\
1 \\
25 \\
5 \\
3 \\
1 \\
1 \\
1 \\
2 \\
1\end{array}$ & $\begin{array}{r}17.1 \\
22.2 \\
28.5 \\
0.1 \\
43.0 \\
1.4 \\
3.3 \\
104.3 \\
61.0 \\
0.1 \\
- \\
0.2 \\
1365.1 \\
1.3 \\
4.7 \\
0.5 \\
0.7 \\
- \\
107.4 \\
13.2 \\
17.6 \\
0.6 \\
148.0 \\
5.1 \\
3.3 \\
4.2 \\
8.3 \\
52.0 \\
2.5 \\
1.0 \\
0.9 \\
30.5 \\
54.0 \\
87.5 \\
0.9 \\
0.3 \\
0.3 \\
0.9 \\
0.8\end{array}$ \\
\hline
\end{tabular}

$a_{-}=$not detected. 
ORNL-OWG 78-14554

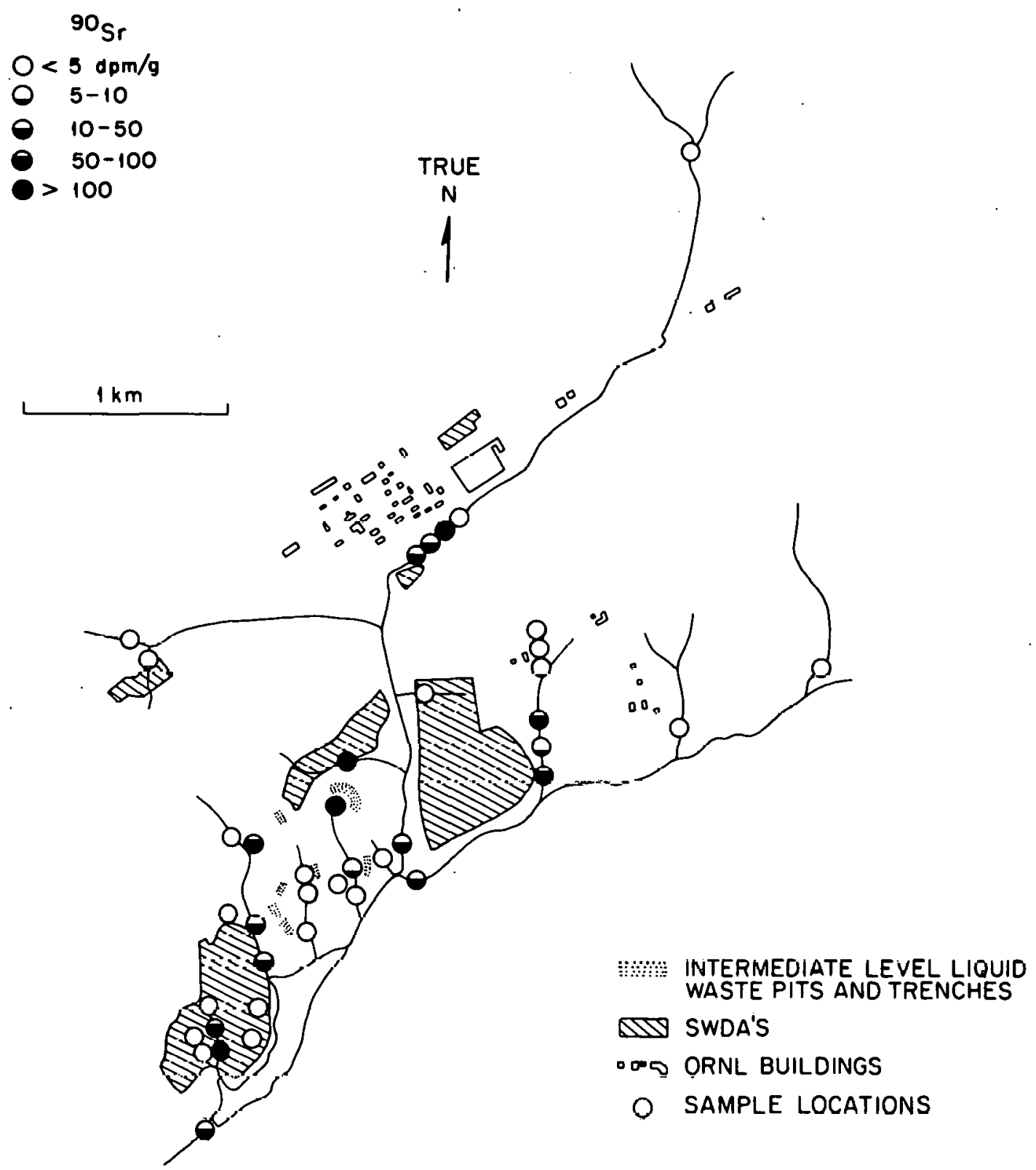

Fig. 7. The distribution of $90 \mathrm{Sr}$ concentrations in streambed sed iment samples from white 0ak creek watershed. 
ORNL-OWG $78-14555$

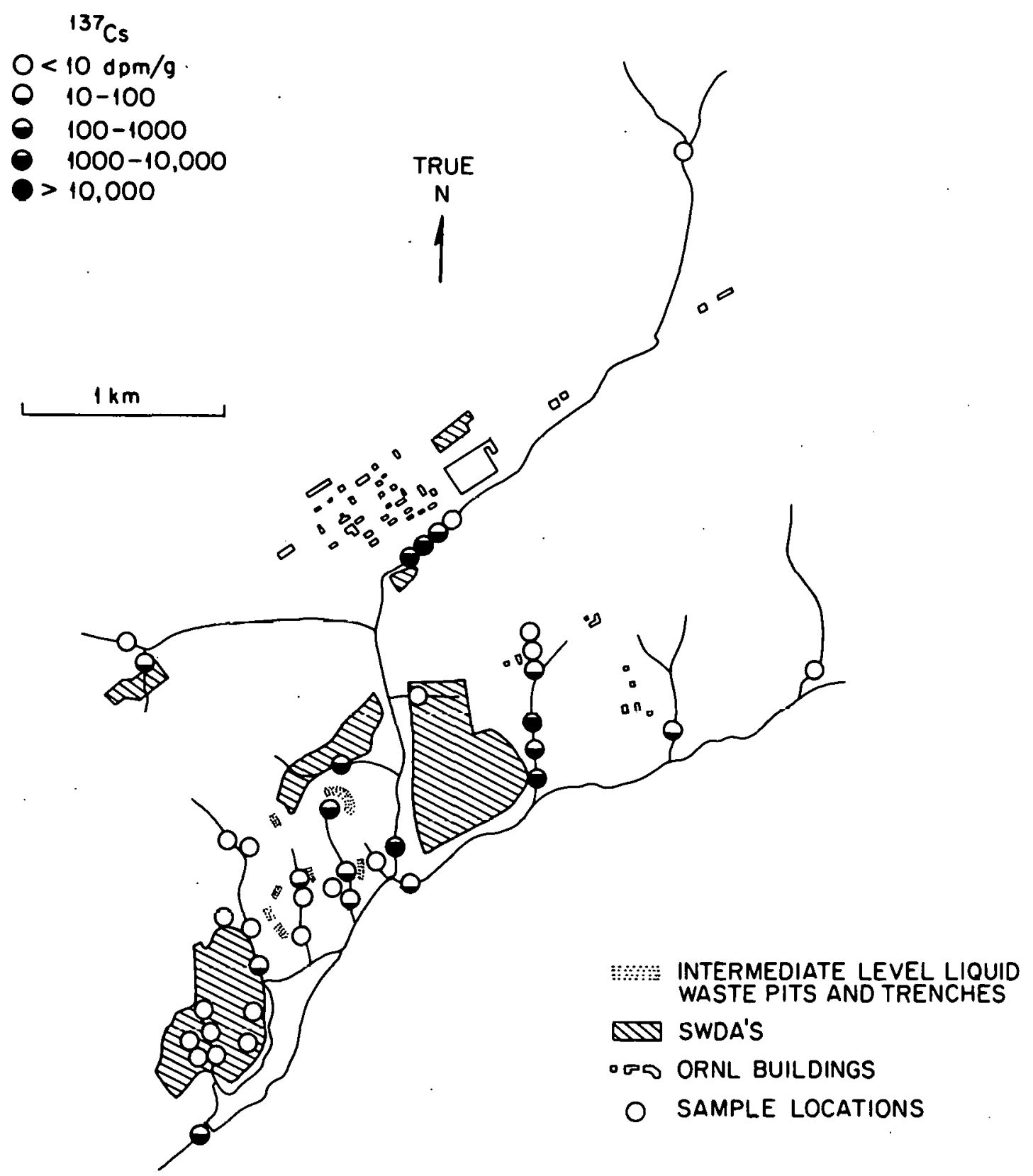

Fig. 8. The distribution of $137 \mathrm{Cs}$ concentrations in streambed sediment samples from White Oak Creek watershed. 


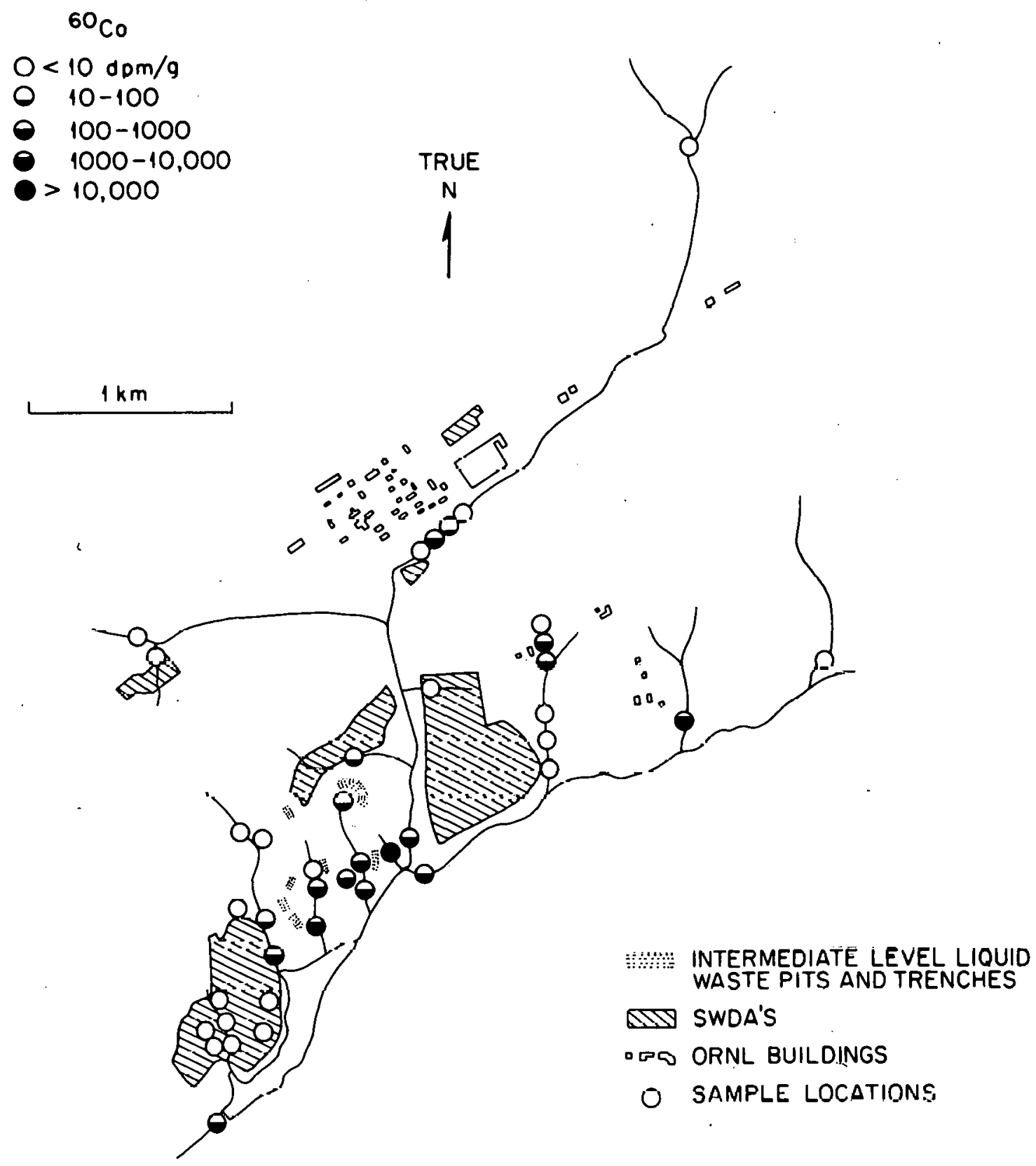

Fig. 9. The distribution of ${ }^{60}$ Co concentrations in streambed sed iment samples from White 0ak Creek watershed. 
Rather significant ${ }^{137}$ Cs concentrations $(\geq 3000 \mathrm{dpm} / \mathrm{g}$ ) were observed at the mouth of the stream east of SWDA-5 (sample 9-9), in White 0ak Creek just below monitoring station 3 (sample 9-2), and near points of entry of ORNL plant effluents into White 0ak Creek (sample 9-22).

Cobalt-60 exhibited a distribution (Fig. 9) quite different from either ${ }^{90} \mathrm{Sr}$ or ${ }^{137}$ Cs. Major sources appear to be ILLW trenches and pits, particularly the well-known seep east of ILLW trench 7 (Means et al. 1978), plant effluent from the main ORNL complex, leakage near the HRI Settling Basin area, and the high flux isotope reactor (HFIR) area (samples 9-4, 9-22, 13-12, and 9-10, respectively). In general, the low concentrations of ${ }^{60} C_{0}$ in the SWDA drainage show that only small amounts, relative to ${ }^{90} \mathrm{Sr}$ and ${ }^{137} \mathrm{Cs}$, originate from the SWDA's. Although the ILLW pits and trenches are repositories for all three of these radionuclides, on $1{ }^{60}$ Co appears to be moving from them. This suggests that the treatment of the intermediate-level liquid waste (high $\mathrm{Na}$ and $\mathrm{pH}$ ) may have led to immobilization of ${ }^{90} \mathrm{Sr}$ and ${ }^{137} \mathrm{Cs}$ in the ILLW pits and trenches. A similar treatment of low-level solid waste or of the soil in which it is to be buried might well lead to better retention of ${ }^{90} \mathrm{Sr}$ and ${ }^{137} \mathrm{Cs}$.

More extensive sampling of streambed sediment is being performed to locate points of entry of radionuclide contamination. Particular attention is being focused on areas where the preliminary samplings indicated large and unknown sources of contamination upstream. Even if radionuclide contamination of stream-water were to be stopped, the sediments themselves pose as a source of contamination for some as yet unestimated time. To estimate how long streambed sediments will remain 
a source of contamination, samples of highly contaminated fine gravel, contained in nylon-mesh bags, will be placed in uncontaminated sections (headwaters) of White Oak Creek. By removing and analyzing these samples at various times, estimates of the in situ rates of radionuclide transfer from sediment to stream water under local conditions can be calculated. In addition, a similar experiment, plaçing uncontaminated gravel in sections of contaminated streams with periodic sampling, should yield a good estimate of the rate of transfer of radionuclides from water to sediment as well as reveal whether contamination is continuing or a result of earlier releases. These two rates should provide enough knowledge to estimate how long streambeds would remain contaminated by each radionuclide as weil as to estimate their rate of transport in the creek. Studies of the concomitant rates of ferromanganese hydrous oxide deposition on streambed sediment should further clarify their role in the adsorption and immobilization of ${ }^{60} \mathrm{Co},{ }^{137} \mathrm{Cs}$, and ${ }^{90} \mathrm{Sr}$ in white Oak Creek.

\section{SUMMARY AND CONCLUSIONS}

This study was initiated to determine how streambed sediments could be used to locate radionuclide contamination in White 0ak Creek watershed. Several conclusions were reached:

(1) The three radionuclides, ${ }^{60} \mathrm{Co},{ }^{90} \mathrm{Sr}$, and ${ }^{137} \mathrm{Cs}$, are retained on streambed sediment by different mechanisms. Cobalt-60 is precipitated with manganese in hydrous oxide coatings on minerals or rock fragments. Strontium-90 occurs primarily as an exchangeable cation on clays, organic matter, iron oxides, and manganese oxides; 
small amounts of ${ }^{90} \mathrm{Sr}$ also occur in a nonexchangeable form in manganese oxides. Cesium-137 is held irreversibly by illitic minerals in the sediments.

(2) Fine gravel to coarse sand is the best size fraction of Conasauga shale-derived sediments for sampling radionuclide contamination. Medium to very fine sand contains more quartz than larger or smaller fractions. $\mathrm{Cl}$ ay and silt size fractions, although they contain radionuclides, are not useful for sampling because they comprise only a small percentage of the stream bottom sediment and because they cannot be readily isolated by sieving when sampled in the field.

(3) White Oak Creek watershed contains several previously unreported sources of contamination such as ${ }^{90} \mathrm{Sr}$ from SWDA-6. A much more comprehensive sampling of White Oak Creek sediments is underway to locate with more precision all sources of contamination entering the watershed. 


\section{REFERENCES}

Adams, F. 1965. Manganese. pp. 1011-1018. IN C.A. Black (ed.), Methods of Soil Analysis. American Society of Agronomy, Madison, Wisconsin.

American Public Health Service. 1975. Total radioactive strontium and strontium-90 in water. pp. 654-660. IN Standard Methods for the Examination of Water and Wastewater. American Public Health Service, Washington, D.C.

Burns, R. G. 1976. The uptake of cobalt into ferromanganese nodules, soils and synthetic manganese (IV) oxides. Geochim. Cosmochim. Acta 40:95-102.

Chao, T. T. 1972. Selective dissolution of manganese oxides from soils and sediments with acidified hydroxylamine hydrochloride. Soil Sci. Soc. Am. Proc. 36:764-768.

Coffin, D. D. 1963. A method for the determination of free iron in soils and clays. Can. J. Soil Sci. 43:1-17.

Jackson, M. L. 1956. Soil Chemical Analysis - Advanced Course (Sixth Printing). Published by the author, Department of Soil science, University of Wisconsin, Madison, Wisconsin.

Jeffries, D. S., and W. Stum. 1976. The metal-adsorption chemistry of buserite. Can. Mineral. 14:16-22.

Jenkinson, D. S. 1966. Studies on the decomposition of plant material in soil. II. Partial sterilization and the soil biomass. J. Soil Sci. 17:280-302. 
Jenne, E. A. 1968. Controls on $\mathrm{Mn}, \mathrm{Fe}, \mathrm{Co}, \mathrm{Ni}, \mathrm{Cr}$, and $\mathrm{Zn}$ concentrations in soils and water: The significant role of hydrous $\mathrm{Mn}$ and Fe oxides. Am. Chem. Soc. Adv. Chem. Ser. 73:337-387.

Kiely, P. V., and M. L. Jackson. 1964. Selective dissolution of micas from potassium feldspar by sodium pyrosulfate fusion of șoils and sediments. Am. Minera 1. 49:1648-1659.

Kiely, P. V., and M. L. Jackson. 1965. Quartz, feldspar and mica determination for soils by sodium pyrosulfate fusion. Soil Sci. Soc. Am. Proc. 29:159-163.

Kinniburgh, D. G., J. K. Syers, and M. L. Jackson. 1975. Specific adsorption of trace amounts of calcium and strontium by hydrous oxides of iron and aluminum. Soil Sci. Soc. Am. Proc. 39:464-470.

Kinniburgh, D. G., M. L. Jackson, and J. K. Syers. 1976. Adsorption of alkaline earth, transition, and heavy metal cations by hydrous oxide gels of iron and aluminum. Soil Sci. Soc. Am. J. 40:796-799. Loganathan, P., R. G. Burau, and D. W. Fuerstenau. 1977. Influence of $\mathrm{pH}$ on the sorptiun of $\mathrm{Cu}^{2+}, \mathrm{Zn}^{2+}$, and $\mathrm{Ca}^{2+}$ by hydrous manganese oxide. Soil Sci. Soc. Am. J. 41:57-62.

McKeague, J. A., and J. H. Day. 1966. Dithionite- and oxalateextractable $\mathrm{Fe}$ and $\mathrm{Al}$ as aids in differentiating various classes of soils. Can. J. Soil Sci. 46:13-22.

McKenzie, R. M. 1977. Manganese oxides and hydroxides. pp. 181-193. IN J. B. Dixon and S. B. Weed (eds.), Minerals in Soil Environments. Soil Science Society of America, Madison, Wisconsin. 
Means, J. L., D. A. Crerar, and J. 0. Duguid. 1978. Migration of radioactive waste: Radionuclide mobilization by complexing agents. Science 200:1477-1481.

Stueber, A. M., D. E. Edgar, A. F. McFadden, and T. G. Scott. 1978. Preliminary investigation of ${ }^{90} \mathrm{Sr}$ in white 0ak Creek between monitoring stations 2 and 3. ORNL/TM-6510. Oak Ridge National Laboratory, Oak Ridge, Tennessee. 78 pp.

Tamura, T. 1963. Cesium sorption reactions as indicator of clay mineral structures. Clays Clay Miner. 10:389-398.

Tamura, T., and D. G. Jacobs. 1960. Structural implications in cesium sorption. Health Phys. 2:391-398.

Taylor, R. M., R. M. Mckenzie, and K. Norrish. 1964. The mineralogy and chemistry of manganese in some Australian soils. Aust. J. Soil Res. 2:235-248.

Whitney, P. R. 1975. Relationship of manganese-1ron oxides and associated heavy metals to grain size in stream sediments. J. Geochem. Explor. 4:251-263. 
ORNL/TM-6895

INTERNAL DISTRIBUTION

1. H. S. Arora

2-16. S. I. Auerbach

17. E. A. Bondiet ti

18-32. T. E. Cerling

33. J. A. Cox

34. N. H. Cutshall

35. R. J. Floran

36. C. W. Franc is

37. R. B. Fitts

38. J. R. Gissel

39. D. D. Huff

40. I. L. Larsen

41. L. C. Lasher

42. R: S. Lowrie

43. R. J. Luxmoore
44. T. W. Oakes

45. H. A. Pfuderer

46. S. A. Reynolds

47. R. A. Robinson

48. T. G. Scott

49-63. B. P. Spalding

64. J. R. Stokely

65. T. Tamura

66. G. T. Yeh

67. ESD Library

68-69. Central Research Library

70-71. Laboratory Records Department

72. Laboratory Records, ORNL-RC

73. ORNL Y-12 Technical Library

74. ORNL Patent Office

\section{EXTERNAL DISTRIBUTION}

75. Office of Assistant Management, Energy Research and Development, DOE-ORO

76. E. L. Albenesius, Savannah River Laboratory, Aiken, SC 29801

77. William J. Coppoc, Texaco, Inc., P.0. Box 509, Beacon, NY 12508

78. J. R. Cove11, Savannah River Operations Office, P. 0. Box A, Aiken, SC 29801

79. G. H. Daly, Chief, Operations Branch, Waste Products Division, Department of Energy, Washington, DC 20545

80. S. N. Davis, Head, Department of Hydrology and Water Resources, University of Arizona, Tucson, AZ 85721

81. G. D. DeBuchananne, U. S. Geological Survey, Reston, VA 22092

82. D. E. Edgar, Argunne National Laboratory, Argonne, IL 60439

83. R. M. Garre1s, Department of Geological Sciences, Northwestern University, Evanston, IL 60201

84. B. D. Guilbeault, Richland Operations Office, Richland, WA 99352

85. E. A. Jenne, U. S. Geological Survey, Menlo Park, CA 94025

86. D. E. Large, Oak Ridge Operations Office, Department of Energy, P. 0. Box E, Oak Ridge, TN 37830

87. George H. Lauff, Director, W. K. Kellogg Biological Station, Michigan State University, Hickory Corners, MI 49060

88. J. H. Lenhard, Oak Ridge Operations Office, Department of Energy, P. O. Box E, Oak Ridge, TN 37830

89. Simon A. Levin, Section of Ecology and Systematics, Bldg. No. 6, Langmuir Laboratory, Cornell University, Ithaca, NY 14850

90. John J. Magnuson, Laboratory of Limnology, The University of Wisconsin, Madison, WI 53706

91. Helen McCammon, Division of Ecological Research, Department of Energy, Washington, DC 20545 
92. J. L. Means, Battelle Columbus Laboratories, 505 King Avenue, Columbia, OH 43201

93. R. L. Morgan, Office of Nuclear Waste Management, Department of Energy, Washington, DC 20545

94. G. Oerte1, Division of Waste Products, Department of Energy, Washington, DC 20545

95. A. Perge, Special Staff, Office of Nuclear Waste Management, Department of Energy, Washington, DC 20545

96. S. J. Phillips, Battelle-Pac if ic Northwest Laboratories, P. 0. Box 999 , Richland, WA 99352

97. R. J. Serne, Battelle-Pac if ic Northwest Laboratories, P. 0. Box 999, Richland, WA 99352

98. J. G. Steger, Los Alamos Scientific Laboratory, P.0. Box 1663, Los Alamos, NM 87545

99. Richard H. Waring, Department of Forest Science, Oregon State University, Corvallis, OR 97331

100. D. A. Webster, U. S. Geological Survey, Building 3504, ORNL

101-127. Technical Information Center, Oak Ridge, TN 37830 